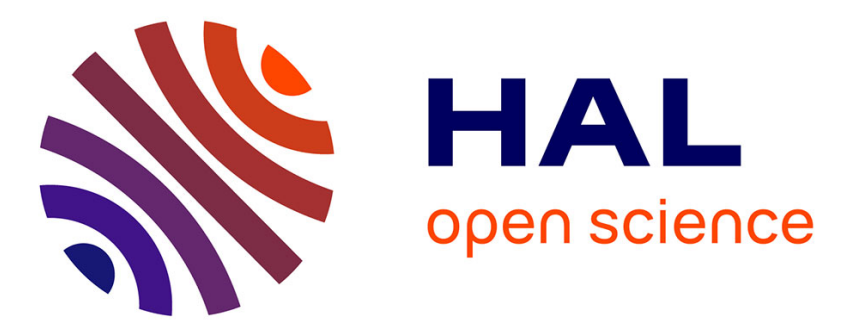

\title{
s-Tetrazine Dyes: A Facile Generation of Photoredox Organocatalysts for Routine Oxidations
}

Tuan Le, Thibaut Courant, Jérémy Merad, Clémence Allain, Pierre Audebert, Géraldine Masson

\section{- To cite this version:}

Tuan Le, Thibaut Courant, Jérémy Merad, Clémence Allain, Pierre Audebert, et al.. s-Tetrazine Dyes: A Facile Generation of Photoredox Organocatalysts for Routine Oxidations. Journal of Organic Chemistry, 2019, 84 (24), pp.16139-16146. 10.1021/acs.joc.9b02454 . hal-03328321

\section{HAL Id: hal-03328321 https://hal.science/hal-03328321}

Submitted on 29 Aug 2021

HAL is a multi-disciplinary open access archive for the deposit and dissemination of scientific research documents, whether they are published or not. The documents may come from teaching and research institutions in France or abroad, or from public or private research centers.
L'archive ouverte pluridisciplinaire HAL, est destinée au dépôt et à la diffusion de documents scientifiques de niveau recherche, publiés ou non, émanant des établissements d'enseignement et de recherche français ou étrangers, des laboratoires publics ou privés. 


\title{
s-Tetrazine Dyes: A Facile Generation of Photoredox Organocatalysts for Routine Oxidations
}

\author{
Tuan Le, $₫$ \$ Thibaut Courant, $\uparrow, \S$ Jérémy Mérad, †Clémence Allain, ${ }_{, \ddagger}^{*}$ Pierre \\ Audebert,, and Géraldine Masson $*, \uparrow$
}

†Institut de Chimie des Substances Naturelles, CNRS UPR 2301, Université Paris-Sud, Université Paris-Saclay, 1, av. de la Terrasse, 91198 Gif-sur-Yvette Cedex, France

‡PPSM, ENS Paris-Saclay, CNRS, Université Paris-Saclay, 94235 Cachan, France

ABSTRACT: A series of organic dyes derived from s-tetrazine have been synthesized, and their photophysical and electrochemical properties are systematically investigated. Testing these compounds as photoredox catalysts in a model oxidative C-S bond cleavage of thioethers has led us to identify new classes of active s-tetrazines. Moreover, some of them can be formed in situ from commercially available 3,6-dichlorotetrazine, making this photocatalyzed C-S bond functionalization simple and highly practical.

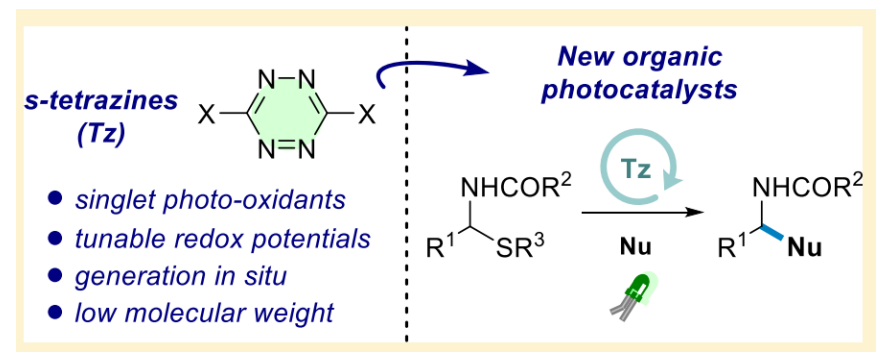

\section{INTRODUCTION}

In recent years, visible light photoredox catalysis has turned out to become a powerful ally to drive ion-radical redox reactions under mild reaction conditions. ${ }^{1}$ In this context, $\mathrm{Ru}(\mathrm{II})$ and $\mathrm{Ir}(\mathrm{III})$ polypyridyl complexes have been extensively used as sensitizers, owing to their exceptional photophysical properties (Scheme 1a). ${ }^{1,2}$ On the other hand, this unique reactivity is offset by high costs, toxicity, and scarcity in metal resources, a situation responsible for the limited exports of photoredox catalysis out of academic laboratories. An alternative is provided by the use of naturally occurring dyes as sensitizers (such as methylene blue and eosin Y, Scheme 1b). ${ }^{3}$ Consequently, identifying new organic scaffolds as nontoxic, inexpensive, and eco-friendly photocatalysts has recently become a dynamic research area. As a result of these extensive investigations, original structures like cyanoarenes (i.e., 4CzIPN) and acridinium salts (i.e., Mes-acr+) have been brought to light (Scheme 1b). ${ }^{4}$ Although these examples of organic sensitizers represent important advances, the development of accessible and cheap metal-free photocatalysts is still highly desirable.

As part of our continuing efforts to develop novel photocatalytic processes5 and design new organic fluorophores, 6 we have recently turned our attention to s- tetrazines (1,2,4,5-tetrazines $\mathbf{2}$, Scheme 1). These electroactive heterocycles show high electron affinity and can be reversibly reduced into their anion-radical counterpart. Their reduction potential can be tuned by the nature of the aromatic substituents. In addition, we 6 and others 7 have demonstrated that appropriately substituted tetrazines absorb visible light while displaying long fluorescence lifetimes and high quantum yields. Despite this attractive profile, as far as we are aware, only 3,6- di(pyridin-2yl)-1,2,4,5-tetrazine 1 has been employed as a photocatalyst by Biswas et al. (Scheme 1b). 8 However, the imposed structure of this compound only offers a poor modularity of its photoredox performances. Because 3,6- dialkoxy and 3,6-diaryloxy tetrazines $\mathbf{2}$ exhibit significantly improved fluorescence quantum yields compared to 1,6c,e we have assumed that this general scaffold could be the starting point to design original, cheap, and highly efficient photocatalysts. Herein, a comparative study is reported accounting for the ability of various 3,6-dialkoxy and 3,6diaryloxy tetrazines 2 to catalyze the C-S bond cleavage of $\alpha$-carbamoylsulfides under visible-light irradiation (Scheme 1c). In addition, to their synthesis, their electrochemical and spectroscopic properties were investigated and compared to tetrazine 1. Following this studies, we found that an active photocatalyst can be formed in situ 
from commercially available 3,6-dichlorotetrazine $\mathbf{3}$, improving the practical aspect of using tetrazines as photocatalysts.
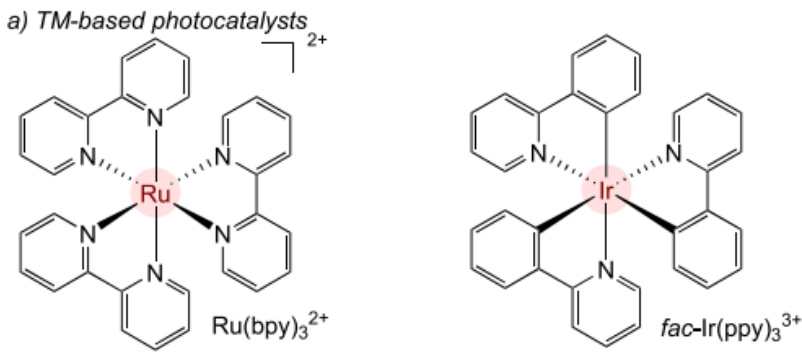<smiles>CN(C)c1ccc2nc3ccc(N(C)C)cc3[s+]c2c1</smiles>

Methylene blue<smiles>Cc1cc(C)c(-c2c3ccccc3[n+](C)c3ccccc23)c(C)c1</smiles><smiles>O=C(O)c1ccccc1C1c2cc(Br)c(O)c(Br)c2Oc2c1cc(Br)c(O)c2Br</smiles><smiles>[R]c1c([R])c(C#N)c([R])c([R])c1C#N</smiles><smiles>c1ccc(-c2nnc(-c3ccccn3)nn2)nc1</smiles><smiles>[R]Oc1nnc(O[R])nn1</smiles>

c) Photocatalyzed oxidative $C-S$ bond functionalizations

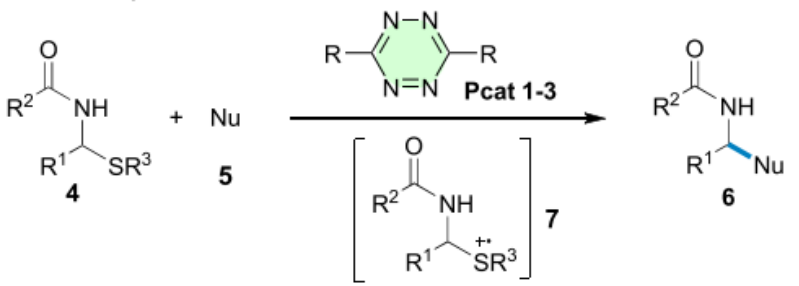

Scheme 1. Selected photocatalysts

\section{RESULTS AND DISCUSSION}

The study started with the synthesis of several substituted stetrazines $\mathbf{2}$, easily prepared by a single nucleophilic aromatic substitution step between commercially available 3,6-dichlorotetrazine $\mathbf{3}$ and various nucleophiles (such as alcohols and pyrazole, Scheme 2). ${ }^{6}$ The etherification process was efficiently conducted in the presence of 2,4,6collidine with phenols and aliphatic alcohols, then affording tetrazines 2a-d with moderate to good yields. Sterically demanding adamantan-1-ylmethanol gave only the monosubstituted product and the addition of 4dimethylaminopyridine (DMAP) was required to promote the second substitution and deliver 2e with $33 \%$ yield. The synthesis of 3,6-di(1H-pyrazol-1-yl)-tetrazine $2 \mathbf{g}$ can be achieved by refluxing pyrazole and $\mathbf{3}$ in $\mathrm{CH}_{3} \mathrm{CN}$.

The photophysical and electrochemical properties of synthesized s-tetrazines 2 were then recorded (Table 1). Dichloromethane solutions of tetrazines $\mathbf{2 a}$ to $\mathbf{2 g}$ display a strong absorption band in the UV region, corresponding to a $\pi-\pi^{*}$ allowed transition (see the UV-vis spectra, Figure S1 in Supporting Information). More interestingly, a less intense band was observed in the green region $(520-530 \mathrm{~nm})$ resulting from a mainly forbidden $\mathrm{n}-\pi^{*}$ transition. Modifying the electronic properties of the substituents of s-tetrazines only had a small impact on the $\lambda_{\max }$ of this last band and allcompounds showed a decent molar extinction coefficient $\left(>500 \mathrm{~cm}^{-1} \mathrm{~L} \mathrm{~mol}^{-1}\right)$. Irradiation of 2 in the green region produces fluorescence emission between 549 and $577 \mathrm{~nm}$ (recorded in dichloromethane) with high fluorescence quantum yields (see the fluorescence spectra, Figure S2 in Supporting Information). 

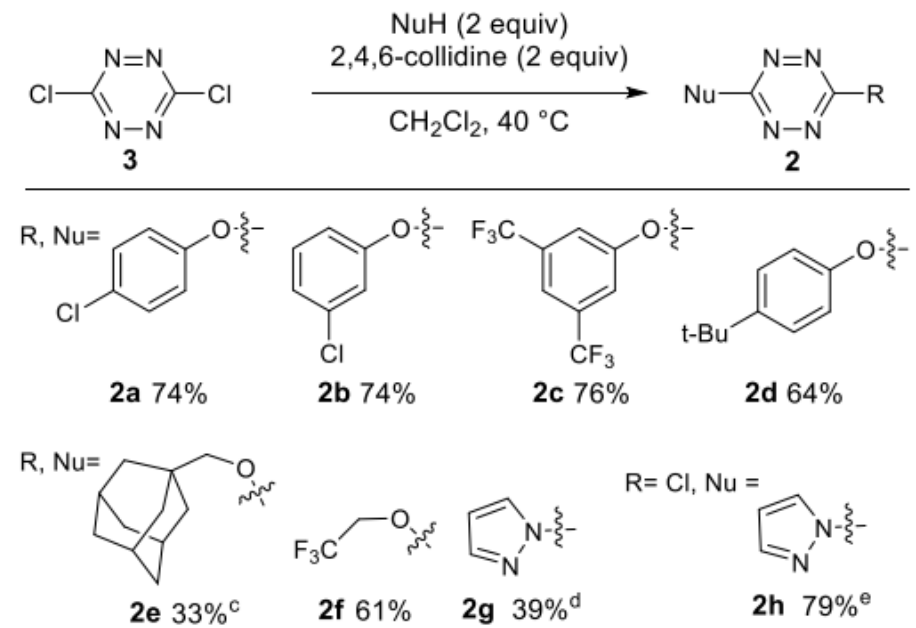

Scheme 2. Synthesis of 3,6-Dialkoxy-tetrazines from 3,6-Dichloro 1,2,4,5-Tetrazine $3^{a, b}$

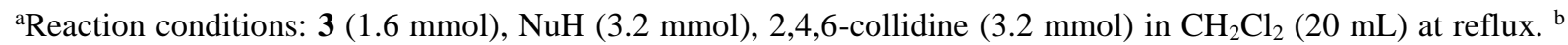
Isolated yields. ${ }^{\mathrm{3}}$ (1.6 mmol), $\mathrm{NuH}(3.2 \mathrm{mmol}), 2,4,6$-collidine $\left(1.6 \mathrm{mmol}, 1\right.$ equiv) in $\mathrm{CH}_{2} \mathrm{Cl}_{2}(20 \mathrm{~mL})$ at reflux followed by addition of DMAP (1.6 mmol). ${ }^{\mathrm{d}}$ With $\mathrm{CH}_{3} \mathrm{CN}$ as solvent. ${ }^{\mathrm{e}}(1.6 \mathrm{mmol}), \mathrm{NuH}(1.6 \mathrm{mmol}), 2,4,6$ collidine $(1.6 \mathrm{mmol})$ in $\mathrm{CH}_{2} \mathrm{Cl}_{2}(20 \mathrm{~mL})$ at reflux.

However, the presence of electron donor groups on the phenoxy moiety led to complete extinction of the fluorescence for tetrazines $\mathbf{2 d}$ with no measurable quantum yield, this presumably because of an intramolecular electron-transfer from the electron-rich substituent to the tetrazine core. Similar results were observed with aliphatic alkyl groups such as the adamantyl. Interestingly, 3,6-bis-(2,2,2-trifluoroethoxy)- 1,2,4,5-tetrazine (2c) is highly fluorescent. Excited state lifetimes were extrapolated from the rates of fluorescence decays and turned out to be long for compounds 2a-c, $\mathbf{2 f}$ (60-165 ns, Figure S3, in Supporting Information). It is important to notice that commonly employed photoredox catalysts usually perform single electron transfer (SET) from their long living (up to ms) triplet excited state. However, it is established that direct photoexcitation of stetrazines does not lead to intersystem crossing and phosphorescence is only observed in specific cases. ${ }^{9}$ Theoretically, SET from the singlet or triplet states are equally fast, only back electron transfer from the radical ionic product is faster in the case of the singlet state. ${ }^{10}$ This feature pushed us to believe that highly fluorescent s-tetrazines with a long lifetime of excited state could emerge as unique singlet photoredox catalysts suitable for wide-range oxidations.

\begin{tabular}{cclclll} 
entry & Pcat $\mathbf{2}$ & \multicolumn{1}{c}{$\lambda_{\text {abs }}, \mathrm{nm}$} & $\varepsilon$ & $\lambda_{\text {em }}, \mathrm{nm}$ & $\phi_{\mathrm{f}}$ & $\tau$, ns \\
\hline 1 & $\mathbf{2 a}^{b}$ & $531,340,232$ & 600 & 577 & 0.14 & 60 \\
2 & $\mathbf{2 b}^{b}$ & 525,350 & 600 & 567 & 0.27 & 130 \\
3 & $\mathbf{2 c}$ & $528,335,258$ & 640 & 563,573 & 0.31 & 165 \\
4 & $\mathbf{2 d}^{b}$ & $530,345,232$ & 500 & 575 & 0.005 & nd \\
5 & $\mathbf{2 e}^{c}$ & 523,333 & 588 & 574 & 0.07 & 32 \\
6 & $\mathbf{2 f}$ & $520,331,272$ & 680 & 556,566 & 0.32 & 133 \\
7 & $\mathbf{2 g}$ & $520,371,290$ & 600 & 556 & 0.02 & $8^{d}$ \\
8 & $\mathbf{2 h}$ & $517,348,270$ & 420 & 553 & 0.15 & 94 \\
9 & $\mathbf{3}^{c}$ & 515,307 & 460 & 555 & 0.14 & 58
\end{tabular}

Table 1. Photophysical Data for Tetrazines $2 \boldsymbol{a}$ to $2 \mathbf{h}$ and 3 in $\mathrm{CH}_{2} \mathrm{Cl}_{2}{ }^{a}$

${ }^{a} \lambda^{\text {abs }}$ absorption wavelength. $\varepsilon$ molar absorption coefficient $\left(\mathrm{M}^{-1} \mathrm{~cm}^{-1}\right)$ for the first $\lambda_{\text {abs }}$ value, $\lambda_{\text {em }}$, emission wavelength, $\phi f$ fluorescence quantum yield, measured using rhodamine 6G in EtOH as a reference $(\phi f$ ref $=0.95)$, $\tau$ fluorescence lifetime. ${ }^{b}$ Data from ref $6 \mathrm{e}$. ${ }^{\mathrm{c} D a t a}$ from ref $6 \mathrm{f}$. ${ }^{\mathrm{d}} \mathrm{Pure}$ at $>95 \%$ contaminated by inseparable amount of $2 \mathrm{~h}$. ${ }^{\mathrm{e}}$ Data from ref $6 \mathrm{~b}$.

Electrochemical data for s-tetrazines $\mathbf{2 a}$ to $\mathbf{2 g}$ in dichloromethane and using ferrocene as internal reference are reported in Table 2 (see the cyclic voltammograms, Figure S4 in Supporting Information). Measured reduction 
potentials from -0.21 to $-0.86 \mathrm{~V}$ versus saturated calomel electrode (SCE) for tetrazines $\mathbf{2 a}$ to $\mathbf{2 g}$ confirmed their high electron affinity as well as the opportunity to finely tune their reduction potential by modifying lateral chains. The geometry of tetrazines has been optimized using the density functional theory (DFT)/ B3LYP/6-31G(d) method and their electronic properties as the highest occupied molecular orbital (HOMO) and lowest unoccupied molecular orbital (LUMO) levels were examined (see Figures S10-S17 in Supporting Information). It is worth noting that a good correlation was obtained between the reduction potential determined experimentally and the LUMO level obtained from DFT calculations. ${ }^{6 \mathrm{c}}$ An optical gap of $2.17 \mathrm{~V}$ was then applied to calculate the reduction potential of the singlet excited state. The resulting values proved to be significantly higher than that displayed by the excited state of some benchmark photoredox catalysts such as $\mathrm{Ru}(\mathrm{bpy}){ }_{3}{ }^{2+}$, eosin $\mathrm{Y}$, fluorescein, $4 \mathrm{CzIPN}$ and similar to that of excited mesitylacridinium $\left(\mathrm{E}^{*}=2.06 \mathrm{~V}\right.$ vs $\left.\mathrm{SCE}\right)$ (Figure 1).

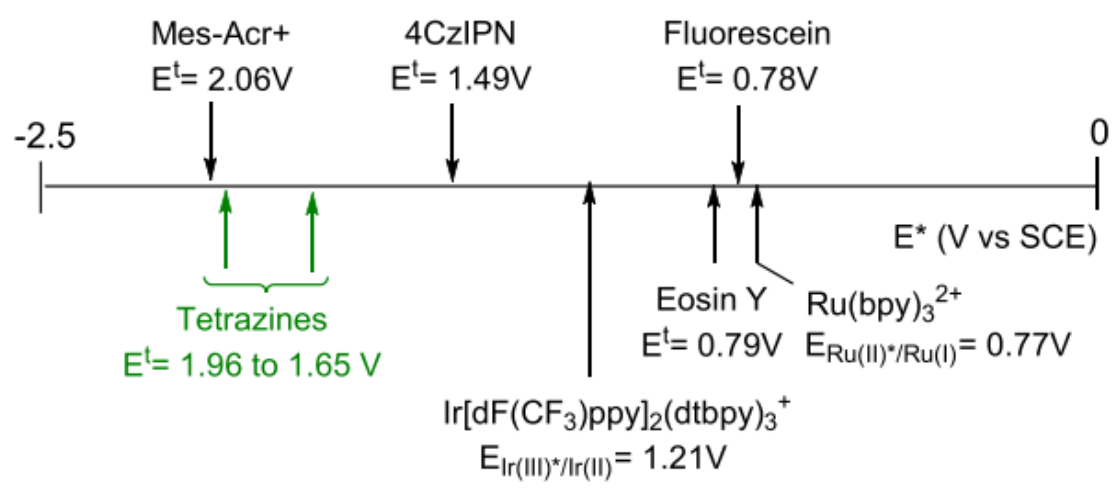

Figure 1. Electrochemical scale

\begin{tabular}{|c|c|c|c|c|c|}
\hline entry & Pcat 2 & $E^{0}\left(\mathrm{Tz} / \mathrm{Tz}^{-\bullet}\right.$ vs $\left.^{\mathrm{Fc}^{+}} / \mathrm{Fc}^{-}\right)$ & $E^{0}\left(\mathrm{Tz} / \mathrm{Tz}^{-\bullet}\right.$ vs $\left.\mathrm{SCE}\right)$ & $E^{0}\left(\mathrm{Tz}^{*} / \mathrm{Tz}^{-\bullet}\right.$ vs $\left.\mathrm{Fc}^{+} / \mathrm{Fc}^{-}\right)$ & $E^{0}\left(\mathrm{Tz}^{*} / \mathrm{Tz}^{-\bullet}\right.$ vs SCE $)$ \\
\hline 1 & $2 a^{b}$ & -0.92 & -0.52 & 1.25 & 1.65 \\
\hline 2 & $2 \mathbf{b}^{b}$ & -0.92 & -0.52 & 1.25 & 1.65 \\
\hline 3 & $2 c$ & -0.61 & -0.21 & 1.56 & 1.96 \\
\hline 4 & $2 d^{b}$ & -0.99 & -0.59 & 1.18 & 1.58 \\
\hline 5 & $2 e^{c}$ & -1.26 & -0.86 & 0.91 & 1.31 \\
\hline 6 & $2 f$ & -0.98 & -0.58 & 1.19 & 1.59 \\
\hline 7 & $2 \mathrm{~g}$ & -0.90 & -0.50 & 1.27 & 1.67 \\
\hline 8 & $2 \mathrm{~h}$ & -0.78 & -0.38 & 1.39 & 1.79 \\
\hline 9 & $3^{d}$ & -0.68 & -0.28 & 1.49 & 1.89 \\
\hline
\end{tabular}

Table 2. Electrochemical Data for Tetrazines $2 \boldsymbol{a}$ to $2 \mathbf{h}$ and $\mathbf{3}$ in $\mathrm{CH}_{2} \mathrm{Cl}_{2}{ }^{a}$

${ }^{\mathrm{a}} \mathrm{E} 0\left(\mathrm{Tz} / \mathrm{Tz}^{\bullet-}\right)$ measured in DCM with $1 \mathrm{mM}$ concentration of $2,0.1 \mathrm{M} \mathrm{TBAPF}_{6}$ and ferrocene as internal reference. ${ }^{b}$ Data from ef $6 e .{ }^{c}$ Data from ref $6 f$. ${ }^{\mathrm{d}}$ Data from ref $6 \mathrm{c}$.

In 2016, our group developed a $\mathrm{Ru}(\mathrm{bpy})_{3}(\mathrm{PF})_{6}$-catalyzed coupling reaction of azoles with $\alpha$-carbamoylsulfides through a single-electron oxidation of sulfides. ${ }^{5 \mathrm{~b}, \mathrm{c}}$ In these studies, organic dyes such as eosin Y and 9-mesityl-10methylacridinium provided disappointing results comparatively to $\mathrm{Ru}-(\mathrm{bpy})_{3}\left(\mathrm{PF}_{6}\right)_{2}$. Therefore, identifying efficient organic dyes able to compete with $\mathrm{Ru}$ complexes in oxidative $\mathrm{C}-\mathrm{S}$ bond functionalization is still highly motivating. This reaction was then selected as a model to evaluate the performances of s-tetrazine dyes 2 . $^{5 b-d, 11}$

Based on the singlet excited-state oxidation potentials shown in Table 2, most of s-tetrazines 2 should be able to oxidize the $\alpha$-carbamoylsulfides (Eox $=+1.18 \mathrm{~V}$ vs SCE) 5 c through a SET oxidation. As a matter of fact, irradiation with green lightemitting diodes (LEDs) of $\mathbf{2 a}(10 \mathrm{~mol} \%)$ under an $\mathrm{O}_{2}$ atmosphere in $\mathrm{CH}_{3} \mathrm{CN}$ in the presence of tert-butyl-(1-(ethylthio)-3-phenylpropyl) carbamate (4a) with pyrazole (5a) led to the formation of desired adduct 6a with 33\% yield after $20 \mathrm{~h}$ (Table 3, entry 2). Meanwhile, tetrazine 1 was nearly unreactive under these conditions (entry 1). As speculated, dye $\mathbf{2 b}$ (entry 3 ) with comparable photoredox properties gave a similar yield. s-Tetrazine $\mathbf{2 c}$ (with higher quantum yield incorporating m-bis-(trifluoromethyl)-group afforded $6 \mathbf{6}$ with the higher yield (entry 4) while weakly fluorescent compound 2d provided 33\% yield of 6 a (entry 5). Surprisingly, better conversion was observed when using less fluorescent compound $\mathbf{2 e}$ compared to $\mathbf{2 f}$ and $\mathbf{2 g}$ (entry 6 vs entry 7). Bis-pyrazole tetrazine $\mathbf{2 g}$ also showed promising results as the photocatalyst for the coupling reaction (entry 8). We then imagine that the addition of an acidic additive able to stabilize radical anions could improve the 
reaction efficiency. ${ }^{5 \text {-d, }, 11}$ Indeed, in the presence of 2,2,2-trifluoroethanol (TFE), $\mathbf{2 c}$ and $\mathbf{2 g}$ catalyze the formation of 6a with an excellent yield of $93 \%$ (entries 9 and 10). To our delight, the use of commercially fluorescent 3,6dichlorotetrazine 3 results in an efficient C-N bond formation (entry 11). However, a careful analysis of the reaction progress allows us to detect the in situ formation of 3-chloro-6-(1H-pyrazol-1-yl)-1,2,4,5- tetrazine (2h), resulting from a nucleophilic monosubstitution by pyrazole. We then synthesized this compound (see Supporting Information) and demonstrated that it was the active catalytic species when the reaction was conducted with $\mathbf{3}$ (entry 12). As a confirmation, compound $\mathbf{2 h}$ displayed similar photophysical properties (excited-state lifetime, absorption spectral features, and fluorescence, Table 1) to $\mathbf{2 c}$ while with a lower oxidation potential (Table 2). Other solvents and additives have been tested in combination with $\mathbf{3}$ without any significant improvement of the yields being observed (see Supporting Information). Under these conditions, catalyst $4 \mathrm{CzIPN}, \mathrm{Ru}(\mathrm{bpy})_{3} \mathrm{Cl}_{2}$ and 9mesityl-10-methylacridinium tetrafluoroborate (Mes-Acr ${ }^{+}$) afforded the adduct 6a in lower yields (entries 16-18), thus clearly demonstrating the superiority of tetrazines over other photocatalysts in C-S bond functionalization (entry 16, Table 3). We also briefly screened other solvents for the process. However, the yield was substantially decreased when the reaction was conducted in $\mathrm{CH}_{2} \mathrm{Cl}_{2}$ or tetrahydrofuran (THF) instead of $\mathrm{CH}_{3} \mathrm{CN}$ (entries 19 and 20).

Table 3. Optimization of the Oxidative C-S Bond Functionalizations

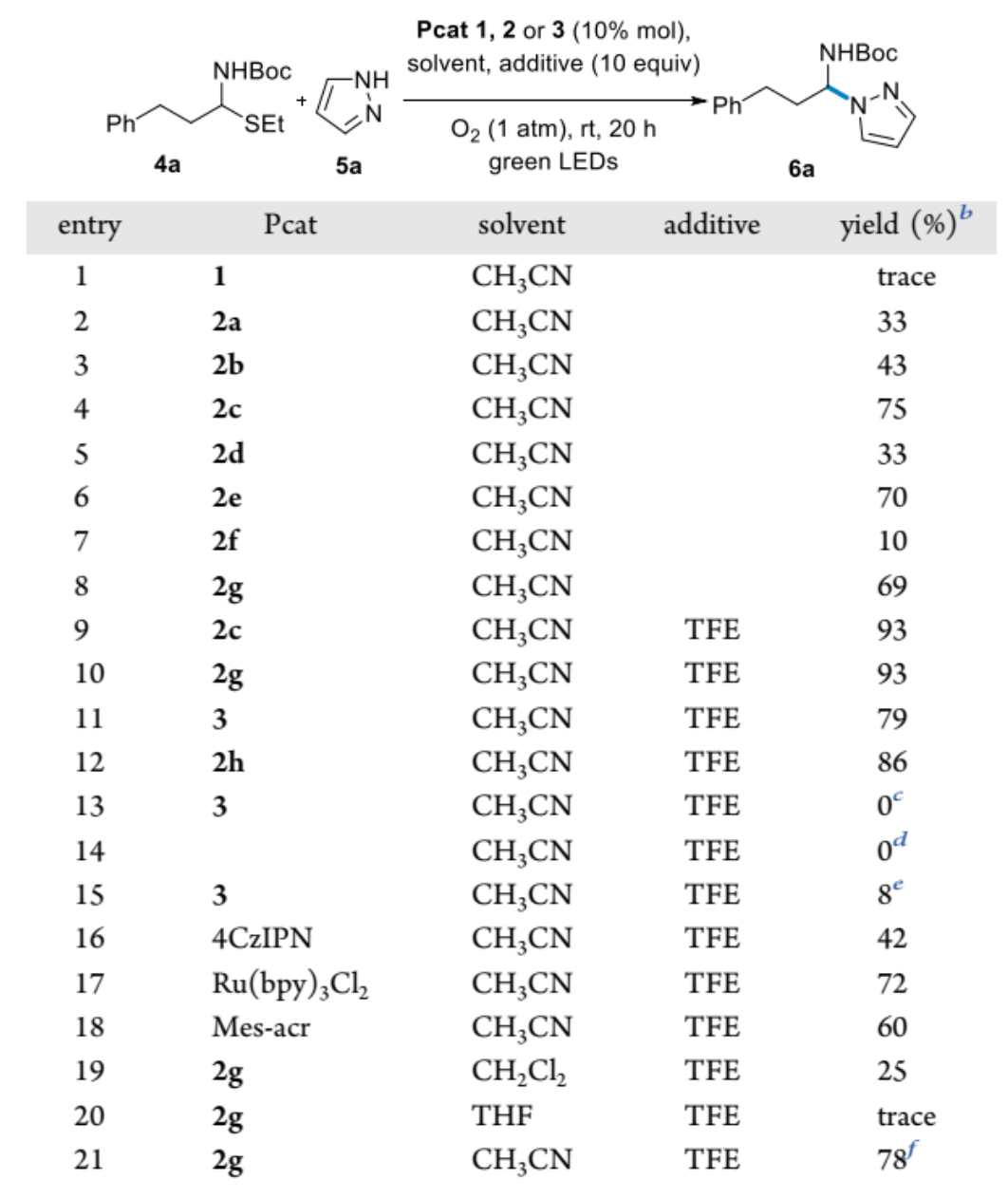

${ }^{a}$ General conditions: $\mathbf{4 a}\left(0.10 \mathrm{mmol}, 1\right.$ equiv), $\mathbf{5 a}(0.15 \mathrm{mmol}), \mathbf{2}\left(0.10\right.$ equiv in $\mathrm{CH}_{3} \mathrm{CN}(1 \mathrm{~mL})$ irradiated with 5 $\mathrm{W}$ green LEDs at $\mathrm{rt}$ for $20 \mathrm{~h}$. ${ }^{\mathrm{b}}$ Isolated yields. ${ }^{\mathrm{c}}$ Reaction performed in the dark. ${ }^{\mathrm{d}}$ Reaction conducted without Pcat. ${ }^{\mathrm{e}}$ Reaction conducted under an argon atmosphere. ${ }^{\mathrm{f}}$ Reaction conducted with chlorocyclohexane.

With the optimized reaction conditions, the scope of the photocatalyzed oxidative C-S bond functionalization was investigated next (Scheme 3). In order to propose a turnkey process, the reaction scope was first explored by using the commercially available precatalyst $\mathbf{3}$. Electron-rich and -poor pyrazoles, as well as benzopyrazole and benzoimidazole are effective reaction partners because they afford the corresponding coupling products $\mathbf{6 b}-\mathbf{g}$ in 
moderate to good yields. In addition, $\alpha$-carbamoyl sulfides bearing either linear and branched alkyl chains or silyl ethers reacted smoothly to deliver $56-80 \%$ of the desired adducts $\mathbf{6 h - 6 1}$. As expected, tetrazines $\mathbf{2 c}$ and $\mathbf{2 g}$ efficiently catalyze the C-N bond formation $(6 \mathbf{c}, 6 \mathbf{d}, \mathbf{6 f}, 6 \mathbf{h}, \mathbf{6 j}, \mathbf{6 h}$, and $6 \mathbf{l})$. To our delight, when 1 equiv of chlorocyclohexane was added in the reaction of $\mathbf{4 a}$ and $\mathbf{5 a}$, the desired coupling product was exclusively formed in a similar yield, thus showing satisfactory tolerance with halogen groups (Table 3, entry 21). ${ }^{12}$ The reaction of $\mathrm{C}-\mathrm{C}$ bonds is also promoted by tetrazines $\mathbf{2 g}$ and $\mathbf{3}$ when trimethoxybenzene was used instead of pyrazole $(\mathbf{6 m})$. Surprisingly, nearly no product $6 \mathrm{~m}$ was observed when using $2 \mathrm{c}$ as a catalyst. To our delight, the photocatalytic aza-Friedel-Craft reaction can be applied to aromatic and aliphatic $\alpha$-amidosulfides ( $6 \mathbf{n}$ and $\mathbf{6 p}$ ). Finally, thiophene and indole readily participate in nucleophilic addition giving rise, respectively, to 60 and $\mathbf{6 p}$ in a decent yield. The model reaction could also be scaled up to $1 \mathrm{mmol}$ scale giving $89 \%$ of desired compound 6 a showing that tetrazine photocatalysis could be a very inexpensive way to perform photoredox reaction on a large scale (see Supporting Information).

\section{Scheme 3. Scope of the Reaction for Oxidative C-S Bond Functionalization ${ }^{a}$}
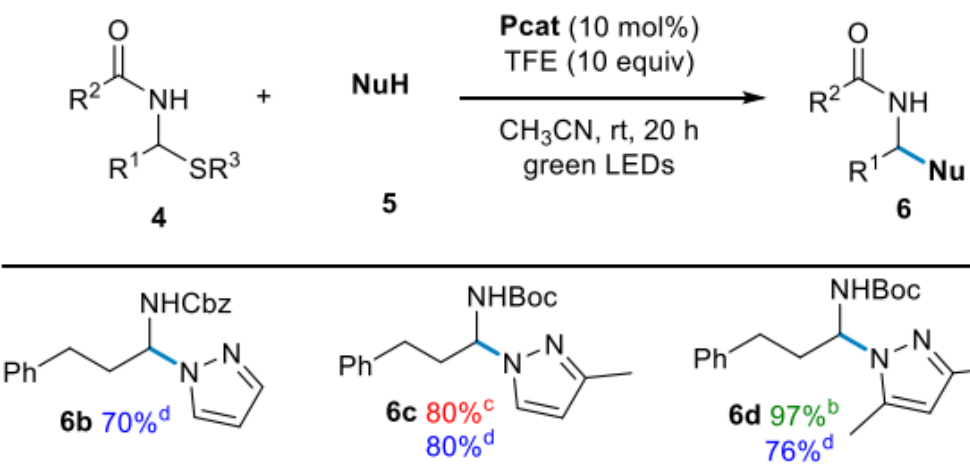<smiles>Cc1cc(C)n(C(CCc2ccccc2)NC(=O)OC(C)(C)C)n1</smiles><smiles>CC(C)(C)OC(=O)OC(N)C(CCc1ccccc1)n1cc([N+](=O)[O-])cn1</smiles><smiles>O=C([18O])NC(CCc1ccccc1)n1ncc2ccccc21</smiles><smiles>O=C(N[C@H](CCc1ccccc1)c1ccccc1)n1cnc2ccccc21</smiles><smiles>CCCC(NC(=O)OC(C)(C)C)n1cccn1</smiles>

6h $99 \%{ }^{c}$ $71 \%^{\mathrm{d}}$<smiles>CCCC(NC(=O)OC(C)(C)C)n1nc(C)cc1C</smiles>
$6 \mathbf{i} 80 \%^{\mathrm{d}}$<smiles>CC(C)C(NC(=O)OCc1ccccc1)n1cccn1</smiles>

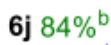
$75 \%^{d}$<smiles>Cc1cc(C)n(C(NC(=O)OC(C)(C)C)C(NC(=O)OC(C)(C)C)C(C)C)n1</smiles><smiles>CCCCOC(=O)OCC(NC(=O)OCc1ccccc1)n1cccn1</smiles><smiles>COc1cc(OC)c(C(CCc2ccccc2)NC(=O)OCc2ccccc2)c(OC)c1</smiles><smiles>COc1cc(OC)c(C(NC(=O)O)c2ccccc2)c(OC)c1</smiles><smiles>COc1ccc(C(CCc2ccccc2)NC(=O)OC(C)(C)C)s1</smiles><smiles>Cc1c(C(CCc2ccccc2)NC(=O)OCc2ccccc2)[nH]c2ccccc12</smiles>

a Reaction conditions: $4(0.10 \mathrm{mmol}), 5(0.15 \mathrm{mmol})$, Pcat $(10 \mathrm{~mol} \%)$, in $\mathrm{CH}_{3} \mathrm{CN}(1 \mathrm{~mL})$ irradiated with $5 \mathrm{~W}$ green LEDs at rt for $20 \mathrm{~h}$. ${ }^{\mathrm{b}}$ Isolated yields with $\mathbf{2 c} .{ }^{\mathrm{c}}$ Isolated yields with $\mathbf{2 g}$. d Isolated yields with 3.

In view to clarify the reaction mechanism, control experiments were conducted. They have pointed out that the reaction does not proceed in the absence of light (Table 3, entry 13) or a photocatalyst (entry 14) while working under an oxygen atmosphere is essential to regenerate the ground state catalyst (entry 15). Stern-Volmer 
fluorescence quenching experiments (see Figures S5 and S6 in Supporting Information) established that $\alpha$ carbamoylsulfides is the fluorescence quencher for the excited state of s-tetrazine dye $\mathbf{2} \mathbf{h}$.

Based on our previous studies and the above results, ${ }^{5 b, c}$ a possible reaction mechanism is proposed in Scheme $4 .{ }^{1}$ Upon irradiation, s-tetrazine $\mathbf{2 h}$ in situ generated from $\mathbf{3}$ is excited to its singlet state $\mathbf{8}$ and reductively quenched by $\alpha$-carbamoylsulfides 4 to generate tetrazine radical anion 9 and sulfur radical cation $\mathbf{1 0}$ via SET oxidation. Subsequent C-S bond cleavage affords N-carbamoyl iminium $\mathbf{1 1}$ and thiylradical which dimerizes fast (isolation of disulfide supports the mechanism, see Figure S7 in Supporting Information). Meanwhile, photocatalyst $\mathbf{2 h}$ is regenerated by the reduction of oxygen to the superoxide radical anion $\left(\mathrm{O}_{2}{ }^{\circ}\right)$. Nucleophilic addition of pyrazole 5 and deprotonation by $\mathrm{O}_{2}{ }^{-13}$ ultimately afford the desired product $\mathbf{6}$. To confirm the formation of $\mathrm{O}_{2}{ }^{*}$, the reactions

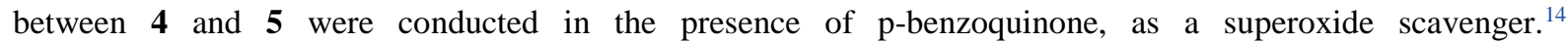
Coupling product 6a was obtained in only $20 \%$ yield (see Figure S8 in Supporting Information), indicating that the formation of a superoxide radical is a crucial step in this photocatalyzed process. A control experiment using the iodinestarch indicator (see Figure S9 in Supporting Information) $)^{15}$ highlighted the presence of $\mathrm{H}_{2} \mathrm{O}_{2}(\mathrm{see}$ Scheme 4) at the end of the reaction probably generated by disproportionation of the hydroperoxyl $\operatorname{radical}\left(\mathrm{HO}_{2}{ }^{\circ}\right)$.

\section{Scheme 4. Suggested Reaction Mechanism for ElectronRich Substrates}

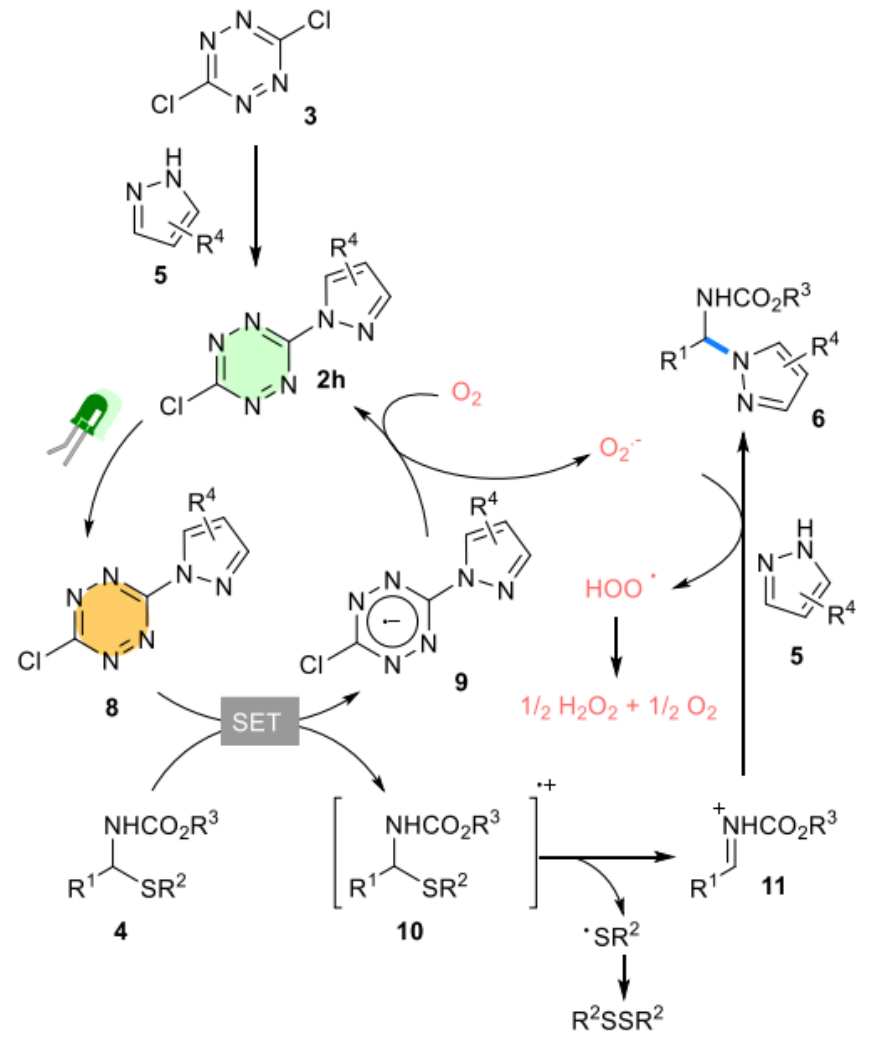

\section{CONCLUSIONS}

In conclusion, we have designed and prepared new s-tetrazine dyes displaying a high oxidative ability. These compounds are among the smallest photoredox catalysts reported in the literature and can be generated in situ from commercially available compounds. Moreover, their redox properties can be tuned by modifying the substitution patterns. These advantages make them easy to handle and quickly accessible. Their efficiency has been demonstrated in a model C-S bond functionalization where they competed efficiently with benchmark catalysts like $\mathrm{Ru}(\mathrm{bpy}){ }_{3}{ }^{2+}$. Finally, we expect that thiswork could be the starting point of an increased use of simple tetrazines to perform routine day-to-day chemical oxidations.

\section{EXPERIMENTAL SECTION}

Materials and Methods. Technical grade solvents were used for quantitative flash chromatography. HPLC grade solvents purchased from Sigma-Aldrich or freshly distilled solvents were used for flash chromatography for 
compounds undergoing full characterization. Reaction solvents were purchased from Acros $99.8 \%$ grade on molecular sieves. All other commercially available reagents were purchased from Acros, Aldrich, Fluka, VWR, Aplichem or Merck and used without any further purification. 3,6-Dichloro-1,2,4,5-s-tetrazine was purchased from Sigma-Aldrich. Chromatography was performedon silica gel (60-240 mesh) unless otherwise specified. Analytical thin layer chromatography (TLC) was performed on silica gel plates (Merck 60F254) visualized either with a UV lamp $(254 \mathrm{~nm})$ or by using permanganate, phosphomolybdic acid, or ninhydrin stain. Organic extracts were dried over anhydrous MgSO4. ${ }^{1} \mathrm{H}$ NMR and ${ }^{13} \mathrm{C}$ NMR spectra were recorded on a Bruker DPX-500, at $500 \mathrm{MHz}\left({ }^{1} \mathrm{H}\right.$ value) or $125 \mathrm{MHz}\left({ }^{13} \mathrm{C}\right.$ value $)$ in $\mathrm{CDCl}_{3}$. Spectra were referenced to residual chloroform $\left(7.26 \mathrm{ppm},{ }^{1} \mathrm{H} ; 77.0 \mathrm{ppm}\right.$, ${ }^{13} \mathrm{C}$ ) or tetramethylsilane. Chemical shifts are reported in ppm, multiplicities are indicated by s (singlet), $\mathrm{d}$ (doublet), t (triplet), q (quartet), qt (quintet), and m (multiplet or unresolved), br (broad signal). Coupling constants, $\mathrm{J}$, are reported in hertz $(\mathrm{Hz})$. All NMR spectra were obtained at $300 \mathrm{~K}$ unless otherwise specified. High-resolution mass spectra (HRMS) were recorded using electrospray ionization(ESI) and a time-of-flight (TOF) analyzer in positive-ion or negative ion detection mode. Reactions were irradiated using a Flexled Inspire LED lamp (45 LEDs, $7.2 \mathrm{~W}, \lambda=535 \mathrm{~nm}$ ) at a $5 \mathrm{~cm}$ distance and using a cooling fan to keep the temperature at $25{ }^{\circ} \mathrm{C}$. Amidosulfides starting materials were synthesized according the literature procedure. ${ }^{16}$

General Protocol for Azole Coupling. To a solution of amidosulfide (0.1 mmol, 1.0 equiv) in acetonitrile $(0.1$ M) were added suitable nucleophile $(0.15 \mathrm{mmol}, 1.5$ equiv) and s-tetrazine photocatalyst $(0.01 \mathrm{mmol}, 10 \% \mathrm{~mol})$ followed by TFE ( $1 \mathrm{mmol}, 10$ equiv, $80 \mu \mathrm{L}$ ). The reaction was flushed with $\mathrm{O}_{2}$ (bubbling) for 5 min and then stirred at room temperature overnight under an $\mathrm{O}_{2}$ atmosphere. The reaction was irradiated with green LEDs (535 $\mathrm{nm}$ ) for $20 \mathrm{~h}$. Completion of the reaction was checked by TLC. Solvents were removed in vacuo and the residue was purified by flash chromatography (pet. ether/ethyl acetate) to give the desired product.

Compounds 6a to $\mathbf{6 p}$ except $\mathbf{6 1}$ were previously described in the literature. Data are in accordance with literature values. $^{5 a, b}$

tert-Butyl(3-phenyl-1-(1H-pyrazol-1-yl)propyl)carbamate $(\mathbf{6 a})^{5 \mathrm{~b}}$ was obtained following the general protocol for azole coupling. With 2c $28 \mathrm{mg}, 93 \%, \mathbf{2 g} 28 \mathrm{mg}, 93 \%, 324 \mathrm{mg}, 79 \%$, (pet. ether/ethyl acetate 4:1 as eluent). ${ }^{1} \mathrm{H}\left\{{ }^{13} \mathrm{C}\right\} \mathrm{NMR}\left(\mathrm{CDCl}_{3}, 300 \mathrm{MHz}\right): \delta(\mathrm{ppm}) 7.63(\mathrm{~s}, 1 \mathrm{H}), 7.57(\mathrm{~s}, 1 \mathrm{H}), 7.31(\mathrm{t}, \mathrm{J}=7.2 \mathrm{~Hz}, 2 \mathrm{H}), 7.22(\mathrm{t}, \mathrm{J}=7.1 \mathrm{~Hz}$, $1 \mathrm{H}), 7.15(\mathrm{~d}, \mathrm{~J}=7.6 \mathrm{~Hz}, 2 \mathrm{H}), 6.26(\mathrm{~s}, 1 \mathrm{H}), 5.84(\mathrm{~d}, \mathrm{~J}=9.2 \mathrm{~Hz}, 1 \mathrm{H}), 5.77(\mathrm{~m}, 1 \mathrm{H}), 2.54-2.51(\mathrm{~m}, 3 \mathrm{H}), 2.43-2.36$ $(\mathrm{m}, 1 \mathrm{H}), 1.42(\mathrm{~s}, 9 \mathrm{H}) .13 \mathrm{C}\{1 \mathrm{H}\} \mathrm{NMR}(\mathrm{CDCl} 3,75 \mathrm{MHz}): \delta(\mathrm{ppm}) 154.7,140.3,140.2,130.0,128.6(2 \mathrm{C}), 128.5$ (2C), 126.3, 104.9, 80.3, 66.4, 36.0, 31.5, 28.3 (3C).

Benzyl(3-phenyl-1-(1H-pyrazol-1-yl)propyl)carbamate $(\mathbf{6 b})^{5 \mathrm{~b}}$ was obtained following the general protocol for azole coupling. With $323 \mathrm{mg}, 70 \%$, (pet. ether/ethyl acetate 4:1 as eluent). ${ }^{1} \mathrm{H}\left\{{ }^{13} \mathrm{C}\right\} \mathrm{NMR}\left(\mathrm{CDCl}_{3}, 300 \mathrm{MHz}\right): \delta$ (ppm) $7.65(\mathrm{~s}, 1 \mathrm{H}), 7.60(\mathrm{~s}, 1 \mathrm{H}), 7.40-7.20(\mathrm{~m}, 8 \mathrm{H}), 7.14-7.11(\mathrm{~m}, 2 \mathrm{H}), 6.41(\mathrm{~d} \mathrm{br}, \mathrm{J}=9.2 \mathrm{~Hz}, 1 \mathrm{H}), 6.28(\mathrm{~s}$, $1 \mathrm{H}), 5.81(\mathrm{t}, \mathrm{J}=8.1 \mathrm{~Hz}, 1 \mathrm{H}), 5.16(\mathrm{~d}, \mathrm{~J}=12.1 \mathrm{~Hz}, 1 \mathrm{H}), 5.00(\mathrm{~d}, \mathrm{~J}=12.3 \mathrm{~Hz}, 1 \mathrm{H}), 2.63-2.32(\mathrm{~m}, 4 \mathrm{H}) .13 \mathrm{C}\{1 \mathrm{H}\}$ NMR (CDCl3, $75 \mathrm{MHz}): \delta(\mathrm{ppm}) 155.5,140.4,140.1,136.0,130.1,128.6(2 \mathrm{C}), 128.5(2 \mathrm{C}), 128.4$ (2C), 128.2 , $128.1,126.3,126.1,105.0,67.1,66.8,35.8,31.4$.

tert-Butyl(1-(3-methyl-1H-pyrazol-1-yl)-3-phenylpropyl)carbamate $(\mathbf{6 c})^{5 \mathrm{~b}}$ was obtained following the general protocol for azole coupling. With 2c $25 \mathrm{mg}, 80 \%, 325 \mathrm{mg}, 80 \%$, (pet. ether/ethyl acetate $4: 1$ as eluent). ${ }^{1} \mathrm{H}\left\{{ }^{13} \mathrm{C}\right\}$ NMR ( $\left.\mathrm{CDCl}_{3}, 300 \mathrm{MHz}\right): \delta(\mathrm{ppm})$ 7.47-7.40 (m, 1H), 7.28-7.24 (m, 2H), 7.20-7.15 (m, 1H), 7.12-7.09 (m, 2H), 5.98-5.96 (m, 1H), 5.82-5.75 (m, 1H), 5.63-5.56 (m, 1H), 2.56- $2.40(\mathrm{~m}, 3 \mathrm{H}), 2.29(\mathrm{~s}, 3 \mathrm{H}), 2.25(\mathrm{~m}, 1 \mathrm{H}), 1.38(\mathrm{~s}$, 9H). ${ }^{13} \mathrm{C}\left\{{ }^{1} \mathrm{H}\right\} \mathrm{NMR}\left(\mathrm{CDCl}_{3}, 75 \mathrm{MHz}\right): \delta$ (ppm) 149.5, 139.5, 130.9, $128.6(2 \mathrm{C}), 128.5,126.3,104.9,104.5,66.3$, $62.5,36.1,31.6,28.4$ (3C), 13.9, 10.8 .

tert-Butyl(1-(3,5-dimethyl-1H-pyrazol-1-yl)-3-phenylpropyl)-carbamate $(\mathbf{6 d})^{5 \mathrm{~b}}$ was obtained following the general protocol for azole coupling. With 2c $32 \mathrm{mg}, 97 \%, 325 \mathrm{mg}, 76 \%$, (pet. ether/ethyl acetate 4:1 as eluent). ${ }^{1} \mathrm{H}\left\{{ }^{13} \mathrm{C}\right\} \mathrm{NMR}\left(\mathrm{CDCl}_{3}, 300 \mathrm{MHz}\right): \delta(\mathrm{ppm}) 7.32-7.13(\mathrm{~m}, 5 \mathrm{H}), 6.10(\mathrm{~d} \mathrm{br}, \mathrm{J}=9.2 \mathrm{~Hz}, 1 \mathrm{H}), 5.77(\mathrm{~s}, 1 \mathrm{H}), 5.70$ $(\mathrm{m}, 1 \mathrm{H}), 2.52-2.33(\mathrm{~m}, 4 \mathrm{H}), 2.27(\mathrm{~s}, 3 \mathrm{H}), 2.24(\mathrm{~s}, 3 \mathrm{H}), 1.42(\mathrm{~s}, 9 \mathrm{H}) .{ }^{13} \mathrm{C}\left\{{ }^{1} \mathrm{H}\right\} \mathrm{NMR}\left(\mathrm{CDCl}_{3}, 75 \mathrm{MHz}\right): \delta(\mathrm{ppm})$ 154.8, 148.4, 140.7, 139.6, 128.5 (2C), 128.4 (2C), 126.1, 104.7, 79.0, 62.2, 36.4, 31.5, 28.3 (3C), 13.7, 10.7.

tert-Butyl(1-(4-nitro-1H-pyrazol-1-yl)-3-phenylpropyl)carbamate $(\mathbf{6 e})^{5 \mathrm{~b}}$ was obtained following the general protocol for azole coupling. With $322 \mathrm{mg}, 63 \%$, (pet. ether/ethyl acetate $4: 1$ as eluent). ${ }^{1} \mathrm{H}\left\{{ }^{13} \mathrm{C}\right\}$ NMR $\left(\mathrm{CDCl}_{3}, 300 \mathrm{MHz}\right): \delta(\mathrm{ppm}) 8.29$ (s br, 1H), 8.15 (s, 1H), 7.36-7.23 (m, 3H), 7.16-7.13 (m, 2H), 5.73-5.57 (m, 2H), 2.67- $2.32(\mathrm{~m}, 4 \mathrm{H}), 1.44(\mathrm{~s}, 9 \mathrm{H}) .{ }^{13} \mathrm{C}\left\{{ }^{1} \mathrm{H}\right\} \mathrm{NMR}\left(\mathrm{CDCl}_{3}, 75 \mathrm{MHz}\right): \delta(\mathrm{ppm}) 154.3,139.3,136.4,135.3$, 128.8 (2C), 128.3 (2C), 126.7 (2C), 81.4, 68.2, 35.1, 31.3, 28.2 (3C). 
tert-Butyl(1-(1H-indazol-1-yl)-3-phenylpropyl)carbamate $(\mathbf{6} \mathbf{f})^{5 \mathrm{~b}}$ was obtained following the general protocol for azole coupling. With $\mathbf{2 g} 31 \mathrm{mg}, 88 \%, 328 \mathrm{mg}, 79 \%$, (pet. ether/ethyl acetate $3: 1$ as eluent). ${ }^{1} \mathrm{H}\left\{{ }^{13} \mathrm{C}\right\} \mathrm{NMR}\left(\mathrm{CDCl} \mathrm{C}_{3}\right.$, $300 \mathrm{MHz}): \delta(\mathrm{ppm}) 8.14(\mathrm{~s} \mathrm{br}, 1 \mathrm{H}), 7.79(\mathrm{dd}, \mathrm{J}=8.8$ and $0.9 \mathrm{~Hz}, 1 \mathrm{H}), 7.72(\mathrm{dt}, \mathrm{J}=8.4$ and $1.0 \mathrm{~Hz}, 1 \mathrm{H}), 7.38-7.20$ $(\mathrm{m}, 4 \mathrm{H}), 7.16-7.11(\mathrm{~m}, 3 \mathrm{H}), 6.49(\mathrm{~d} \mathrm{br}, \mathrm{J}=9.0 \mathrm{~Hz}, 1 \mathrm{H}), 6.07(\mathrm{~m}, 1 \mathrm{H}), 2.72-2.48(\mathrm{~m}, 4 \mathrm{H}), 1.39(\mathrm{~s}, 9 \mathrm{H}) .{ }^{13} \mathrm{C}\left\{{ }^{1} \mathrm{H}\right\}$ $\mathrm{NMR}\left(\mathrm{CDCl}_{3}, 75 \mathrm{MHz}\right): \delta(\mathrm{ppm}) 154.7,143.6,141.3,139.5,132.5,128.7$ (2C), 128.4 (2C), 126.6, 123.2, 122.6, $120.3,110.8,80.8,62.4,36.0,31.7,28.2(3 \mathrm{C})$.

tert-Butyl(1-(1H-benzo[d]imidazole-1-yl)-3-phenylpropyl)-carbamate (6g)5b was obtained following the general protocol for azole coupling. With $2 \mathrm{~g} 21 \mathrm{mg}, 59 \%$, (pet. ether/ethyl acetate $1: 1$ as eluent). ${ }^{1} \mathrm{H}\left\{{ }^{13} \mathrm{C}\right\} \mathrm{NMR}\left(\mathrm{CD}_{3} \mathrm{CN}\right.$ $\left.+\mathrm{D}_{2} \mathrm{O}, 500 \mathrm{MHz}\right): \delta(\mathrm{ppm}) 8.08(\mathrm{~s}, 1 \mathrm{H}), 7.73-7.56(\mathrm{~m}, 2 \mathrm{H}), 7.36-7.16(\mathrm{~m}, 7 \mathrm{H}), 6.56(\mathrm{br} \mathrm{s}, 1 \mathrm{H}), 5.92(\mathrm{q}, \mathrm{J}=7.1$ $\mathrm{Hz}, 1 \mathrm{H}), 2.78-2.40(\mathrm{~m}, 4 \mathrm{H}), 1.36(\mathrm{~s}, 9 \mathrm{H}),{ }^{13} \mathrm{C}\left\{{ }^{1} \mathrm{H}\right\} \mathrm{NMR}\left(\mathrm{CDCl}_{3}, 75 \mathrm{MHz}\right): \delta(\mathrm{ppm}) 154.7,143.6,141.3,139.5$, 132.5, 128.7 (2C), 128.4 (2C), 126.6, 123.2, 122.6, 120.3, 110.8, 80.8, 62.4, 36.0, 31.7, 28.2 (3C).

tert-Butyl(1-(1H-pyrazol-1-yl)octyl)carbamate $(\mathbf{6 h})^{5 \mathrm{~b}}$ was obtained following the general protocol for azole coupling. With $2 \mathrm{~g} 29 \mathrm{mg}, 99 \%, 321 \mathrm{mg}, 71 \%$, (pet. ether/ethyl acetate 4:1 as eluent). ${ }^{1} \mathrm{H}\left\{{ }^{13} \mathrm{C}\right\} \mathrm{NMR}(\mathrm{CDCl} 3,300$ $\mathrm{MHz}): \delta(\mathrm{ppm}) 7.48(\mathrm{~s}, 2 \mathrm{H}), 6.13(\mathrm{~s}, 1 \mathrm{H}), 5.72$ (br s, 1H), 5.52 (br s, 1H), 2.12 (br s, 1H), 1.98 (br s, 1H), 1.33 (s, $9 \mathrm{H}), 1.28-1.08(\mathrm{~m}, 10 \mathrm{H}), 0.78(\mathrm{t}, \mathrm{J}=6.7 \mathrm{~Hz}, 3 \mathrm{H}) .{ }^{13} \mathrm{C}\left\{{ }^{1} \mathrm{H}\right\} \mathrm{NMR}\left(\mathrm{CDCl}_{3}, 75 \mathrm{MHz}\right): \delta(\mathrm{ppm}) 154.8,140.0,129.6$, 104.7, 80.2, 67.2, 34.7, 31.6, 29.1, 29.0, 29.0, $28.3(\times 3), 25.3,22.5,14.0$.

tert-Butyl(1-(3,5-dimethyl-1H-pyrazol-1-yl)octyl)carbamate $(\mathbf{6 i})^{5 \mathrm{~b}}$ was obtained following the general protocol for azole coupling. With $326 \mathrm{mg}, 80 \%$, (pet. ether/ethyl acetate $4: 1$ as eluent). ${ }^{1} \mathrm{H}\left\{{ }^{13} \mathrm{C}\right\} \mathrm{NMR}\left(\mathrm{CDCl}_{3}, 300 \mathrm{MHz}\right): \delta$ (ppm) $5.74(\mathrm{~s}, 1 \mathrm{H}), 5.71-5.59(\mathrm{~m}, 2 \mathrm{H}), 2.35(\mathrm{~s}, 3 \mathrm{H}), 2.23(\mathrm{~s}, 3 \mathrm{H}), 2.16-1.88(\mathrm{~m}, 2 \mathrm{H}), 1.41(\mathrm{~s}, 9 \mathrm{H}), 1.34-0.99$ $(\mathrm{m}, 10 \mathrm{H}), 0.87(\mathrm{t}, \mathrm{J}=6.7 \mathrm{~Hz}, 3 \mathrm{H}) .{ }^{13} \mathrm{C}\left\{\left\{{ }^{1} \mathrm{H}\right\} \mathrm{NMR}\left(\mathrm{CDCl}_{3}, 75 \mathrm{MHz}\right): \delta(\mathrm{ppm}) 154.8,148.2,134.4,104.4,79.8\right.$, $62.8,35.3,31.6,29.0,28.7,28.2(3 \mathrm{C}), 25.2,22.5,13.9,13.6,10.7$.

tert-Butyl(2-methyl-1-(1H-pyrazol-1-yl)propyl)carbamate $(\mathbf{6 j})^{5 \mathrm{~b}}$ was obtained following the general protocol for azole coupling. With $2 \mathrm{c} 20 \mathrm{mg}, 84 \%, 318 \mathrm{mg}, 75 \%$, (pet. ether/ethyl acetate $4: 1$ as eluent). ${ }^{1} \mathrm{H}\left\{{ }^{13} \mathrm{C}\right\} \mathrm{NMR}\left(\mathrm{CDCl} \mathrm{C}_{3}\right.$, $300 \mathrm{MHz}): \delta(\mathrm{ppm}) 7.55(\mathrm{~s}, 1 \mathrm{H}), 7.51(\mathrm{~s}, 1 \mathrm{H}), 6.21(\mathrm{~s}, 1 \mathrm{H}), 5.52(\mathrm{~d}, \mathrm{~J}=7.7 \mathrm{~Hz}, 1 \mathrm{H}), 5.37(\mathrm{t}, \mathrm{J}=9.0 \mathrm{~Hz}, 1 \mathrm{H}), 2.38$ $(\mathrm{h}, \mathrm{J}=6.5 \mathrm{~Hz}, 1 \mathrm{H}), 1.40(\mathrm{~s}, 9 \mathrm{H}), 1.06(\mathrm{~d}, \mathrm{~J}=6.6 \mathrm{~Hz}, 3 \mathrm{H}), 0.70(\mathrm{~d}, \mathrm{~J}=6.6 \mathrm{~Hz}, 3 \mathrm{H}) .{ }^{13} \mathrm{C}\left\{{ }^{1} \mathrm{H}\right\} \mathrm{NMR}\left(\mathrm{CDCl} \mathrm{Cl}_{3}, 75\right.$ $\mathrm{MHz}): \delta(\mathrm{ppm}) 155.2,140.0,130.0,104.4,80.1,72.8,33.1,28.2(3 \mathrm{C}), 18.8,18.6$.

tert-Butyl(1-(3,5-dimethyl-1H-pyrazol-1-yl)-2-methyl propyl)-carbamate $(\mathbf{6 k})^{5 \mathrm{~b}}$ was obtained following the general protocol for azole coupling. With $15 \mathrm{mg}, 56 \%$, (pet. ether/ethyl acetate $4: 1$ as eluent). ${ }^{1} \mathrm{H}\left\{{ }^{13} \mathrm{C}\right\} \mathrm{NMR}$ $\left(\mathrm{CDCl}_{3}, 300 \mathrm{MHz}\right): \delta(\mathrm{ppm}) 5.73(\mathrm{~s}, 1 \mathrm{H}), 5.70(\mathrm{~s}, 1 \mathrm{H}), 5.27(\mathrm{t}, \mathrm{J}=9.9 \mathrm{~Hz}, 1 \mathrm{H}), 2.42-2.26(\mathrm{~m}, 4 \mathrm{H}), 2.22(\mathrm{~s}, 3 \mathrm{H})$, $1.40(\mathrm{~s}, 9 \mathrm{H}), 1.08(\mathrm{~d}, \mathrm{~J}=6.6 \mathrm{~Hz}, 3 \mathrm{H}), 0.64(\mathrm{~d}, \mathrm{~J}=6.6 \mathrm{~Hz}, 3 \mathrm{H}) .{ }^{13} \mathrm{C}\left\{{ }^{1} \mathrm{H}\right\} \mathrm{NMR}\left(\mathrm{CDCl}_{3}, 75 \mathrm{MHz}\right): \delta(\mathrm{ppm}) 155.3$, $148.3,139.8,104.4,79.9,68.6,33.9,28.4(3 \mathrm{C}), 19.2,18.7,13.8,11.0$.

tert-Butyl(4-((tert-butyldiphenylsilyl)oxy)-1-(1H-pyrazol-1-yl)-butyl)carbamate (61) was obtained following the general protocol for azole coupling. Colorless oil. With $\mathbf{2 g} 41 \mathrm{mg}, 83 \%, 339 \mathrm{mg}, 80 \%$, (pet. ether/ethyl acetate 4:1 as eluent). ${ }^{1} \mathrm{H}\left\{{ }^{13} \mathrm{C}\right\} \mathrm{NMR}\left(\mathrm{CDCl}_{3}, 300 \mathrm{MHz}\right): \delta(\mathrm{ppm}) 7.74-7.18(\mathrm{~m}, 12 \mathrm{H}), 6.11(\mathrm{t}, \mathrm{J}=1.8 \mathrm{~Hz}, 1 \mathrm{H}), 5.79-$ $5.40(\mathrm{~m}, 2 \mathrm{H}), 3.55(\mathrm{t}, \mathrm{J}=6.2 \mathrm{~Hz}, 2 \mathrm{H}), 2.25-1.91(\mathrm{~m}, 2 \mathrm{H}), 1.46-1.19(\mathrm{~m}+\mathrm{s}, 2 \mathrm{H}+9 \mathrm{H}), 0.96(\mathrm{~s}, 9 \mathrm{H}) ;{ }^{13} \mathrm{C}\left\{{ }^{1} \mathrm{H}\right\} \mathrm{NMR}$ (CDCl3, $75 \mathrm{MHz}$ ): $\delta$ (ppm) 154.7, 139.9, 135.5 (4C), 133.7, 129.6 (4C), 129.5, 127.7 (4C), 104.7, 80.2, 67.1, 63.0, 31.3, 28.3 (3C), 26.8 (3C), 19.2. IR (neat) $\mathrm{cm}^{-1}: 3217,2947,2858,1697,1532,1366,1268,1254,1109,734$; HRMS (ESI-TOF) anal. for $\mathrm{C}_{28} \mathrm{H}_{39} \mathrm{~N}_{3} \mathrm{O}_{3} \mathrm{SiNa}[\mathrm{M}+\mathrm{Na}]^{+}$calcd, 516.2653; found, 516.2663.

tert-Butyl(3-phenyl-1-(2,4,6-trimethoxyphenyl)propyl)carbamate $(\mathbf{6 m})^{5 \mathrm{c}}$ was obtained following the general protocol for azole coupling. With $2 \mathrm{~g} 36 \mathrm{mg}, 90 \%$, (pet. ether/ethyl acetate $4: 1$ as eluent). ${ }^{1} \mathrm{H}\left\{{ }^{13} \mathrm{C}\right\} \mathrm{NMR}\left(\mathrm{CDCl} \mathrm{N}_{3}\right.$, $300 \mathrm{MHz}): \delta(\mathrm{ppm}) 7.28-7.16(\mathrm{~m}, 5 \mathrm{H}), 6.15(\mathrm{~s}, 2 \mathrm{H}), 5.86(\mathrm{br} \mathrm{d}, \mathrm{J}=10.2 \mathrm{~Hz}, 1 \mathrm{H}), 5.43(\mathrm{dd}, 1 \mathrm{H}, \mathrm{J}=9.9$ and $15.3 \mathrm{~Hz}), 3.84(\mathrm{~s}, 3 \mathrm{H}), 3.83(\mathrm{~s}, 6 \mathrm{H}), 2.75-2.65(\mathrm{~m}, 1 \mathrm{H}), 2.53-2.43(\mathrm{~m}, 1 \mathrm{H}), 2.19-1.92(\mathrm{~m}, 2 \mathrm{H}), 1.46(\mathrm{~s}, 9 \mathrm{H})$. $13 \mathrm{C}\{1 \mathrm{H}\} \mathrm{NMR}(\mathrm{CDCl} 3,75 \mathrm{MHz}): \delta(\mathrm{ppm}) 160.2,158.6,155.5,128.3$ (3C), 128.1 (2C), $125.4(2 \mathrm{C}), 111.0,91.1$, $91.0(2 \mathrm{C}), 78.6,55.8,55.2,45.9,37.6,32.9,28.5(3 \mathrm{C})$.

tert-Butyl(phenyl(2,4,6-trimethoxyphenyl)methyl)carbamate $(\mathbf{6 n})^{5 \mathrm{c}}$ was obtained following the general protocol for azole coupling. With $2 \mathrm{~g} 36 \mathrm{mg}, 97 \%, 336 \mathrm{mg}$, 97\%, (pet. ether/ethyl acetate 5:1 as eluent). ${ }^{1} \mathrm{H}\left\{{ }^{13} \mathrm{C}\right\} \mathrm{NMR}$ $\left(\mathrm{CDCl}_{3}, 300 \mathrm{MHz}\right): \delta(\mathrm{ppm}) 7.26-7.11(\mathrm{~m}, 5 \mathrm{H}), 6.59$ (br d, J = 10.1 Hz, 1H), 6.25 (br d, J = 10.2 Hz, $\left.1 \mathrm{H}\right) 6.15$ $(\mathrm{s}, 2 \mathrm{H}), 3.81(\mathrm{~s}, 3 \mathrm{H}), 3.77(\mathrm{~s}, 6 \mathrm{H}), 1.47(\mathrm{~s}, 9 \mathrm{H}) .{ }^{13} \mathrm{C}\left\{{ }^{1} \mathrm{H}\right\} \mathrm{NMR}\left(\mathrm{CDCl}_{3}, 75 \mathrm{MHz}\right): \delta(\mathrm{ppm}) 160.6,158.6,155.7$, 127.8 (3C), $126.0(2 \mathrm{C}), 126.0(2 \mathrm{C}), 111.0(3 \mathrm{C}), 91.2,79.0,55.9,55.3,48.2,28.5$ (3C). 
tert-Butyl(1-(5-methoxythiophen-2-yl)-3-phenylpropyl)carbamate $(\mathbf{6 o})^{5 \mathrm{c}}$ was obtained following the general protocol for azole coupling. With $320 \mathrm{mg}, 58 \%$, (pet. ether/ethyl acetate $3: 1$ as eluent). ${ }^{1} \mathrm{H}\left\{{ }^{13} \mathrm{C}\right\} \mathrm{NMR}\left(\mathrm{CDCl} \mathrm{N}_{3}\right.$, $300 \mathrm{MHz}): \delta(\mathrm{ppm}) 7.22-7.07(\mathrm{~m}, 5 \mathrm{H}), 6.49(\mathrm{~s}, 1 \mathrm{H}), 5.95-5.93(\mathrm{~m}, 1 \mathrm{H}), 4.74-4.59(\mathrm{~m}, 2 \mathrm{H}), 3.78(\mathrm{~s}, 3 \mathrm{H}), 2.65-2.55$ $(\mathrm{m}, 2 \mathrm{H}), 2.05-1.97(\mathrm{~m}, 2 \mathrm{H}), 1.37(\mathrm{~s}, 9 \mathrm{H}) ;{ }^{13} \mathrm{C}\left\{{ }^{1} \mathrm{H}\right\} \mathrm{NMR}\left(\mathrm{CDCl}_{3}, 75 \mathrm{MHz}\right): \delta 165.4,155.2,141.5,132.5,128.6$ (2C), 128.4 (2C), 126.1, 121.8, 103.1, 80.1, 60.4, 50.9, 38.5, 32.5, 28.5 (3C).

tert-Butyl(1-(3-methyl-1H-indol-2-yl)-3-phenylpropyl)carbamate $(\mathbf{6 p})^{5 \mathrm{c}}$ was obtained following the general protocol for azole coupling. With $320 \mathrm{mg}$, 55\%, (pet. ether/ethyl acetate $2: 1$ as eluent). ${ }^{1} \mathrm{H}\left\{{ }^{13} \mathrm{C}\right\} \mathrm{NMR}\left(\mathrm{CDCl} \mathrm{N}_{3}\right.$, $300 \mathrm{MHz}): \delta(\mathrm{ppm}) 8.46$ (s, 1H, NHindole), 7.47 (d, J = 7.7 Hz, 1H), 7.26-7.01 (m, 8H), 4.97 (br s, 1H) 4.71-4.64 $(\mathrm{m}, 1 \mathrm{H}), 2.65-2.48(\mathrm{~m}, 2 \mathrm{H}), 2.36-2.12(\mathrm{~m}, 2 \mathrm{H}), 2.19(\mathrm{~s}, 3 \mathrm{H}), 1.37(\mathrm{~s}, 9 \mathrm{H}) ;{ }^{13} \mathrm{C}\left\{{ }^{1} \mathrm{H}\right\} \mathrm{NMR}\left(\mathrm{CDCl}_{3}, 75 \mathrm{MHz}\right): \delta$ (ppm) 156.0, 141.2, 135.5,134.7, 129.1, 128.6 (2C), 128.5 (2C), 126.2, 121.9, 119.2, 118.7, 110.9, 107.8, 80.2, 48.0, 32.7, 28.5 (3C), 28.1, 8.8.

Synthesis and Data for s-Tetrazines $2 \mathrm{c}$ and $2 \mathrm{e}$ to $\mathbf{2 h}$. sTetrazines $\mathbf{2 a}, \mathbf{2 b}, \mathbf{2 d}$ were prepared according to the reported procedures. ${ }^{6 e}$

Procedure A. To a solution of 3,6-dichlorotetrazine (1.0 equiv) in anhydrous $\mathrm{CH}_{2} \mathrm{Cl}_{2}\left(8 \times 10^{-2} \mathrm{M}\right)$ were added a phenol derivative (2.0 equiv) and then 2,4,6-collidine (2.0 equiv). The resulting mixture was then stirred and heated under reflux until complete conversion (monitored by TLC). The solvent was then removed under reduce pressure and the residue was purified by silica gel flash chromatography $\left(\mathrm{CH}_{2} \mathrm{Cl}_{2} / \mathrm{AcOEt}\right.$ or pet. ether/ $\mathrm{CH}_{2} \mathrm{Cl}_{2}$ gradient). In some cases, the desired product as a precipitate was filtered, washed with cold dichloromethane, and used without further purification.

Procedure B. To a solution of 3,6-dichlorotetrazine (1.0 equiv) in anhydrous $\mathrm{CH}_{2} \mathrm{Cl}_{2}\left(8 \times 10^{-2} \mathrm{M}\right)$ were added a phenol derivative ( 2 equiv) and then 2,4,6-collidine ( 1 equiv). The resulting mixture was then stirred and heated under reflux until complete conversion into the monosubstituted product (monitored by TLC). DMAP (1 equiv) was added and the reaction was kept running for $1 \mathrm{~h}$. The solvent was then removed under reduced pressure and the residue was purified bysilica gel flash chromatography $\left(\mathrm{CH}_{2} \mathrm{Cl}_{2} / \mathrm{AcOEt}\right.$ or pet. ether/ $\mathrm{CH}_{2} \mathrm{Cl}_{2}$ gradient $)$.

3,6-Bis(4-chlorophenoxy)-1,2,4,5-tetrazine (2a).6e It was obtained as a pink solid (397 mg, 74\% yield). Reported (287 mg, 52\% yield). 1H\{13C \} NMR (300 MHz, $\left.\mathrm{CDCl}_{3}\right): \delta(\mathrm{ppm}) 7.43(\mathrm{~d}, \mathrm{~J}=8.9 \mathrm{~Hz}, 4 \mathrm{H}), 7.22(\mathrm{~d}, \mathrm{~J}=8.9 \mathrm{~Hz}$, $4 \mathrm{H}) ; \mathrm{mp} 165-166^{\circ} \mathrm{C}$.

3,6-Bis(3-chlorophenoxy)-1,2,4,5-tetrazine (2b).6e It was obtained as a pink solid (397 mg, 74\% yield). Reported (110 mg, 33\% yield). ${ }^{1} \mathrm{H}\left\{{ }^{13} \mathrm{C}\right\} \mathrm{NMR}\left(300 \mathrm{MHz}, \mathrm{CDCl}_{3}\right): \delta(\mathrm{ppm}) 7.44(\mathrm{t}, \mathrm{J}=8.0 \mathrm{~Hz}, 2 \mathrm{H}), 7.37-7.31(\mathrm{~m}, 4 \mathrm{H}), 7.20-$ $7.18(\mathrm{~d}, \mathrm{~J}=8.0 \mathrm{~Hz}, 2 \mathrm{H})$; $\mathrm{mp} 128-130{ }^{\circ} \mathrm{C}$.

3,6-Bis(3,5-bis(trifluoromethyl)phenoxy)-1,2,4,5-tetrazine (2c). Prepared according to general procedure A in $4 \mathrm{~h}$ from 3,6-dichlorotetrazine (242 mg, $1.6 \mathrm{mmol}), 3,5$-bis(trifluoromethyl)phenol (0.6 mL, $3.2 \mathrm{mmol})$, and 2,4,6collidine $(0.4 \mathrm{~mL}, 3.2 \mathrm{mmol})$ in $\mathrm{CH}_{2} \mathrm{Cl}_{2}(20 \mathrm{~mL})$. No purification needed. It was obtained as a pink solid (655 $\mathrm{mg}$, $76 \%$ yield). ${ }^{1} \mathrm{H}\left\{{ }^{13} \mathrm{C}\right\}$ NMR (300 MHz, $\left.\mathrm{CD}_{3} \mathrm{CN}\right): \delta(\mathrm{ppm}) 8.02(\mathrm{~s}, 2 \mathrm{H}), 7.98(\mathrm{~s}, 4 \mathrm{H}) ;{ }^{19} \mathrm{~F} \mathrm{NMR}\left(282 \mathrm{MHz}, \mathrm{CD}_{3} \mathrm{CN}\right)$ : $\delta(\mathrm{ppm})-63.54 ;{ }^{13} \mathrm{C}\left\{{ }^{1} \mathrm{H}\right\} \mathrm{NMR}(75 \mathrm{MHz}, \mathrm{CD} 3 \mathrm{CN}): \delta(\mathrm{ppm}) 167.0(2 \mathrm{C}), 152.9(2 \mathrm{C}), 132.9(4 \mathrm{C}), 122.0(4 \mathrm{C}), 120.2$ (4C), 117.0 (2C); IR (neat) $v\left(\mathrm{~cm}^{-1}\right): 3055,1406,1347,1264,1174,1133,956,902,847,732,702 ; \mathrm{mp} \mathrm{215-217}$ ${ }^{\circ} \mathrm{C}$. HRMS (ESI-TOF) m/z: [M + Cl]- alcd for $\mathrm{C}_{18} \mathrm{H}_{6} \mathrm{~F}_{12} \mathrm{~N}_{4} \mathrm{O}_{2} \mathrm{Cl}^{-}, 572.9988$; found, 572.9983 .

3,6-Bis(4-(tert-butyl)phenoxy)-1,2,4,5-tetrazine (2d). ${ }^{6 e}$ It was obtained as a pink solid (387 mg, 64\% yield). Reported (403 mg, 93\% yield). ${ }^{1} \mathrm{H}\left\{{ }^{13} \mathrm{C}\right\}$ NMR (500 MHz, DMSO-d6): $\delta$ (ppm) $7.51(\mathrm{~d}, \mathrm{~J}=8.7 \mathrm{~Hz}, 4 \mathrm{H}), 7.29(\mathrm{~d}$, $\mathrm{J}=8.7 \mathrm{~Hz}, 4 \mathrm{H}), 1.32(\mathrm{~s}, 18 \mathrm{H}) ; \mathrm{mp} 267-269^{\circ} \mathrm{C}$.

3,6-Bis(((1S,3S)-adamantan-1-yl)methoxy)-1,2,4,5-tetrazine (2e). Prepared according to general procedure B under reflux from 3,6- dichlorotetrazine (242 mg, $1.6 \mathrm{mmol}), 1$-adamantanemethanol (531 mg, $3.2 \mathrm{mmol}), 2,4,6$ collidine $(0.2 \mathrm{~mL}, 1.6 \mathrm{mmol})$, and DMAP $(195 \mathrm{mg}, 1.6 \mathrm{mmol})$ in $\mathrm{CH}_{2} \mathrm{Cl}_{2}(20 \mathrm{~mL})\left(\mathrm{CH}_{2} \mathrm{Cl}_{2} /\right.$ ethyl acetate $99 / 1$ to $1 / 1$ as eluent). It was obtained as a pink solid (216 mg, 33\% yield). ${ }^{1} \mathrm{H}\left\{{ }^{13} \mathrm{C}\right\} \mathrm{NMR}\left(300 \mathrm{MHz}, \mathrm{CDCl}_{3}\right): \delta(\mathrm{ppm})$ $4.12(\mathrm{~s}, 4 \mathrm{H}), 2.04(\mathrm{~m}, 6 \mathrm{H}), 1.79-1.69(\mathrm{~m}, 24 \mathrm{H}) ; 13 \mathrm{C}\{1 \mathrm{H}\} \mathrm{NMR}\left(75 \mathrm{MHz}, \mathrm{CDCl}_{3}\right): \delta(\mathrm{ppm}) 166.4(2 \mathrm{C}), 79.4(2 \mathrm{C})$, 39.1 (6C), 36.9 (6C), 33.7 (2C), 28.0 (6C); IR (neat) $v\left(\mathrm{~cm}^{-1}\right): 3676,2988,2902,1451,1407,1394,1242,1230$, 1075, 1066, 1057, 892, 880; mp 175-176 ${ }^{\circ} \mathrm{C}$. HRMS (ESITOF) $\mathrm{m} / \mathrm{z}:[\mathrm{M}+\mathrm{H}]^{+}$calcd for $\mathrm{C}_{24} \mathrm{H}_{35} \mathrm{~N}_{4} \mathrm{O}_{2}{ }^{+}, 411.2760$; found, 411.2752 .

3,6-Bis(2,2,2-trifluoroethoxy)-1,2,4,5-tetrazine (2f). Prepared according to general procedure A under reflux from 3,6-dichlorotetrazine $(242 \mathrm{mg}, 1.6 \mathrm{mmol})$, TFE $(0.5 \mathrm{~mL}, 6 \mathrm{mmol})$, and 2,4,6- collidine $(0.4 \mathrm{~mL}, 3.2 \mathrm{mmol}) \mathrm{in}$ 
$\mathrm{CH}_{2} \mathrm{Cl}_{2}$ (20 mL) collection by filtration no purification needed. It was obtained as a pink solid (271 mg, $61 \%$ yield). ${ }^{1} \mathrm{H}\left\{{ }^{13} \mathrm{C}\right\}$ NMR $(300 \mathrm{MHz}, \mathrm{CDCl} 3): \delta(\mathrm{ppm}) 5.01(\mathrm{q}, \mathrm{J}=7.9 \mathrm{~Hz}, 2 \mathrm{H}) ;{ }^{13} \mathrm{C}\left\{{ }^{1} \mathrm{H}\right\}$ NMR $(75 \mathrm{MHz}$, $\mathrm{CDCl} 3): \delta(\mathrm{ppm}) 166.7,122.4\left(\mathrm{q}, \mathrm{J}=277.6 \mathrm{~Hz}, \mathrm{CF}_{3}\right), 65.1(\mathrm{q}, \mathrm{J}=37.7 \mathrm{~Hz}) ;{ }^{19} \mathrm{~F}$ NMR $\left(282 \mathrm{MHz}, \mathrm{CDCl}_{3}\right): \delta(\mathrm{ppm})$ -73.8; IR (neat) $v\left(\mathrm{~cm}^{-1}\right): 3676,2988,2902,1406,1394,1250,1230,1075,1066,892,879 ; \mathrm{mp} 80-82{ }^{\circ} \mathrm{C}$. HRMS (ESI-TOF) m/z: [M - CF3] calcd for $\mathrm{C}_{5} \mathrm{H}_{4} \mathrm{~F}_{3} \mathrm{~N}_{4} \mathrm{O}_{2}{ }^{+}, 209.0286$; found, 209.295.

3,6-Di(1H-pyrazol-1-yl)-1,2,4,5-tetrazine (2g). To a solution of 3,6-dichlorotetrazine (150 mg, $1 \mathrm{mmol}$ ) in $10 \mathrm{~mL}$ acetonitrile was added pyrazole $(136 \mathrm{mg}, 2 \mathrm{mmol})$. The reaction was heated to reflux for $2 \mathrm{~h}$. The reaction was cooled to $0{ }^{\circ} \mathrm{C}$ and the orange-pink precipitate was collected by filtration and washed with cold acetonitrile. The solid was purified by chromatography over silica gel $\left(\mathrm{CH}_{2} \mathrm{Cl}_{2} /\right.$ ethyl acetate $99 / 1$ to $\left.1 / 1\right)$ to give the pure product as an orange solid (102 mg, $48 \%$ yield, $97 \%$ purity with $3 \%$ of $\mathbf{2 h}$ ). ${ }^{1} \mathrm{H}\left\{{ }^{13} \mathrm{C}\right\} \mathrm{NMR}\left(300 \mathrm{MHz}, \mathrm{CDCl}_{3}\right): \delta(\mathrm{ppm})$ $8.75(\mathrm{~m}, 2 \mathrm{H}), 8.06(\mathrm{~m}, 2 \mathrm{H}), 6.71(\mathrm{~m}, 2 \mathrm{H}) ; 13 \mathrm{C}\{1 \mathrm{H}\} \mathrm{NMR}(75 \mathrm{MHz}, \mathrm{CDCl} 3): \delta(\mathrm{ppm}) ; 158.8(2 \mathrm{C}), 146.1(2 \mathrm{C})$, 129.6 (2C), 110.1 (2C). IR (neat) $v\left(\mathrm{~cm}^{-1}\right): 3676,3146,2988,1524,1475,1397,1255,1185,1165,1075,1027$, 953, 918, 888, 773; mp 256-259 ${ }^{\circ} \mathrm{C}$. HRMS (ESI-TOF) m/z: $[\mathrm{M}+\mathrm{CH} 3 \mathrm{CN}+\mathrm{Na}]+\mathrm{m} / \mathrm{z}:[\mathrm{M}+\mathrm{H}]+\mathrm{calcd}$ for $\mathrm{C}_{8} \mathrm{H}_{7} \mathrm{~N}_{8}{ }^{+}, 215.0794$; found, 215.0794 .

3-Chloro-6-(1H-pyrazol-1-yl)-1,2,4,5-tetrazine (2h). To a solution of 3,6-dichlorotetrazine (150 mg, $1 \mathrm{mmol}$ ) in $10 \mathrm{~mL}$ acetonitrile was added pyrazole $(68 \mathrm{mg}, 1 \mathrm{mmol})$. The reaction was stirred at reflux for $1 \mathrm{~h}$. Solvents were removed in vacuo and the resulting solid was purified by chromatography over silica gel $\left(\mathrm{CH}_{2} \mathrm{Cl}_{2}\right.$ /ethyl acetate $99 /$ 1 to $2 / 1)$ to give pure product as an orange solid $\left(73 \mathrm{mg}, 40 \%\right.$ yield) ${ }^{1}{ }^{1} \mathrm{H}\left\{{ }^{13} \mathrm{C}\right\} \mathrm{NMR}\left(300 \mathrm{MHz}, \mathrm{CDCl}_{3}\right)$ : $\delta$ (ppm) 8.70-8.69 (m, 2H), 8.05-8.04 (m, 2H), 6.72-6.70 (m, 2H); ${ }^{13} \mathrm{C}\left\{{ }^{1} \mathrm{H}\right\}$ NMR (75 MHz, CD3CN): $\delta(\mathrm{ppm}) 166.4$, 146.0, 130.0, 117.0, 110.7; IR (neat) $v\left(\mathrm{~cm}^{-1}\right): 3676,3152,2988,2901,1532,1499,1478,1393,1259,1210,1066$, 922, 781; mp 117-119 ${ }^{\circ} \mathrm{C}$. HRMS (ESI-TOF) m/z: $[\mathrm{M}+\mathrm{H}]^{+}$calcd for $\mathrm{C}_{5} \mathrm{H}_{4} \mathrm{ClN}_{6}{ }^{+}, 183.0186$; found, 183.0172 .

\section{ASSOCIATED CONTENT}

The Supporting Information is available free of charge at https://pubs.acs.org/doi/10.1021/acs.joc.9b02454. Control experiments, electrochemical data, UV-vis data, DFT calculation, and ${ }^{1} \mathrm{H},{ }^{13} \mathrm{C}$ NMR data (PDF)

\section{AUTHOR INFORMATION}

Corresponding Authors

*E-mail: clemence.allain@ens-paris-saclay.fr (C.A.)

*E-mail: geraldine.masson@cnrs.fr (G.M.).

ORCID

Clémence Allain: 0000-0002-2908-264X

Pierre Audebert: 0000-0001-9943-7808

Géraldine Masson : 0000-0003-2333-7047

Author Contributions §T.L. and T.C. contributed equally to this work. Notes The authors declare no competing financial interest.

\section{ACKNOWLEDGMENTS}

We thank ICSN for funding. T.C. and J.M. thank the Labex Charm3at for postdoctoral fellowships and T.L. thanks the financial support for Masters. P.A. is grateful to the Institut Universitaire de France for personal and financial support. This work was granted access to the computing resources of CINES (Montpellier, allocation A0050810547 awarded by GENCI). We thank Arnaud Brosseau (PPSM) for his help with the fluorescence lifetime measurements.

\section{REFERENCES}

(1) For selected recent reviews on photoredox catalysis, see: (a) Prier, C. K.; Rankic, D. A.; MacMillan, D. W. C. Visible Light Photoredox Catalysis with Transition Metal Complexes: Applications in Organic Synthesis. Chem. Rev. 2013, 113, 5322. (b) Schultz, D. M.; Yoon, T. P. Solar Synthesis: Prospects in visible light Photocatalysis. Science 2014, 343, 1239176. (c) Karkas, M. D.; Matsuura, B. S.; Stephenson, C. R. J. Enchained by Visible LightMediated Photoredox Catalysis. Science 2015, 349, 1285. (d) Shaw, M. H.; Twilton, J.; MacMillan, D. W. C. Photoredox Catalysis in Organic Chemistry. J. Org. Chem. 2016, 81, 6898. (e) Courant, T.; Masson, G. Recent Progress in Visible-Light Photoredox-Catalyzed Intermolecular 1,2- Difunctionalization of Double Bonds via an ATRA-Type Mechanism. J. Org. Chem. 2016, 81, 6945. (f) Skubi, K. L.; Blum, T. R.; Yoon, T. P. Dual catalysis 
Strategies in Photochemical Synthesis. Chem. Rev. 2016, 116, 10035. (g) Ravelli, D.; Protti, S.; Fagnoni, M. CarbonCarbon Bond Forming Reactions via Photogenerated Intermediates. Chem. Rev. 2016, 116, 9850. (h) Marzo, L.; Pagire, S. K.; Reiser, O.; König, B. Visible-Light Photocatalysis: Does it Make a Difference in Organic Synthesis. Angew. Chem., Int. Ed. 2018, 57, 10034.

(2) (a) Juris, A.; Balzani, V.; Barigelletti, F.; Campagna, S.; Belser, P.; von Zelewsky, A. Ru(II) Polypyridine Complexes: Photophysics, Photochemistry, Electrochemistry, and Chemiluminescence. Coord. Chem. Rev. 1988, 84, 85. (b) Tucker, J. W.; Stephenson, C. R. J. Shining Light on Photoredox Catalysis: Theory and Synthetic Applications. J. Org. Chem. 2012, 77, 1617. (c) Teegardin, K.; Day, J. I.; Chan, J.; Weaver, J. Advances in Photocatalysis: A Microreview of Visible Light Mediated Ruthenium and Iridium Catalyzed Organic Transformations. Org. Process Res. Dev. 2016, 20, 1156. (d) Blakemore, J. D.; Crabtree, R. H.; Brudvig, G. W. Molecular Catalysts for Water Oxidation. Chem. Rev. 2015, 115, 12974.

(3) For selected reviews, see: (a) Ravelli, D.; Fagnoni, M.; Albini, A. Photoorganocatalysis. What For? Chem. Soc. Rev. 2013, 42, 97. (b) Nicewicz, D. A.; Nguyen, T. M. Recent Applications of Organic Dyes as Photoredox Catalysts in Organic Synthesis. ACS Catal. 2014, 4, 355. (c) Romero, N. A.; Nicewicz, D. A. Organic Photoredox Catalysis. Chem. Rev. 2016, 116, 10075. (d) Ghosh, I.; Marzo, L.; Das, A.; Shaikh, R.; König, B. Visible Light Mediated Photoredox Catalytic Arylation Reactions. Acc. Chem. Res. 2016, 49, 1566. (e) Pitre, S. P.; McTiernan, C. D.; Scaiano, J. C. Library of Cationic Organic Dyes for Visible-Light-Driven Photoredox Transformations. ACS Omega 2016, 1, 66. (f) Zeitler, K. Metal-free Photo(redox) Catalysis. In Visible Light Photocatalysis in Organic Chemistry; Stephenson, C. R. J., Yoon, T. P., MacMillan, D. W. C., Eds.; Wiley-VCH: Weinheim, 2018. (g) Sideri, I. K.; Voutyritsa, E.; Kokotos, C. G. Photoorganocatalysis, Small Organic Molecules and Light in the Service of OrganicSynthesis: the Awakening of a Sleeping Giant. Org. Biomol. Chem.2018, 16, 4596. (h) Ray, S.; Samanta, P. K.; Biswas, P. Recent Developments on Visible-Light Photoredox Catalysis by Organic Dyes for Organic Synthesis. In Visible Light-Active Photocatalysis Nanostructured Catalyst Design, Mechanisms, and Applications; Ghosh,S., Ed; Wiley-VCH: Weinheim, 2018.

(4) Selected examples: (a) Fukuzumi, S.; Ohkubo, K. Organic Synthetic Transformations Using Organic Dyes as Photoredox Catalysts. Org. Biomol. Chem. 2014, 12, 6059. (b) Nicewicz, D. A.; Nguyen, T. M. Recent Applications of Organic Dyes as PhotoRedox Catalysts in Organic Synthesis. ACS Catal. 2014, 4, 355. (c) Yang, C.; Yang, J.-D.; Li, Y.-H.; Li, X.; Cheng, J.-P. 9,10-DicyanoanthraceneCatalyzed Decarboxylative Alkynylation of Carboxylic Acids under Visible-Light Irradiation. J. Org. Chem. 2016, 81, 12357. (d) JoshiPangu, A.; Levesque, F.; Roth, H. G.; Oliver, S. F.; Campeau, L.-C.; Nicewicz, D.; DiRocco, D. A. Acridinium-Based Photocatalysts: A Sustainable Option in Photoredox Catalysis. J. Org. Chem. 2016, 81, 7244. (e) Le Vaillant, F.; Garreau, M.; Nicolai, S.; Gryn'ova, G.; Corminboeuf, C.; Waser, J. Fine-Tuned Organic Photoredox Catalysts for Fragmentation-Alkynylation Cascades of Cyclic Oxime Ethers. Chem. Sci. 2018, 9, 5883. (f) Speckmeier, E.; Fischer, T. G.; Zeitler, K. A Toolbox Approach to Construct Broadly Applicable Metal-Free Catalysts for Photoredox Chemistry - Deliberate Tuning of Redox Potentials and Importance of Halogens in Donor-Acceptor Cyanoarenes. J. Am. Chem. Soc. 2018, 140, 15353.

(5) (a) Courant, T.; Masson, G. Photoredox Initiated $\alpha$-Alkylation of Imines via a Three-Component Radical/Cationic Reaction. Chem. Eur. J. 2012, 18, 423. (b) Jarrige, L.; Levitre, G.; Masson, G. Visible-Light Photoredox-Catalyzed Coupling Reaction of Azoles with $\alpha$-Carbamoyl Sulfides. J. Org. Chem. 2016, 81, 7230. (c) Lebee, C.; Languet, M.; Allain, C.; Masson, G. $\alpha$-Carbamoylsulfides as NCarbamoylimine Precursors in the Visible Light PhotoredoxCatalyzed Synthesis of $\alpha, \alpha$-Disubstituted Amines. Org. Lett. 2016, 18, 1478. (d) Lanzi, M.; Merad, J.; Boyarskaya, D. V.; Maestri, G.; Allain, C.; Masson, G. Visible Light-Triggered C-C and C-N Bonds Formation by C-S Bonds Cleavage of Benzylic Thioethers. Org. Lett. 2018, 20, 5247.

(6) For a review, see: (a) Clavier, G.; Audebert, P. s-Tetrazines as Building Blocks for New Functional Molecules and Molecular Materials. Chem. Rev. 2010, 110, 3299. For selected examples, see (b) Audebert, P.; Miomandre, F.; Clavier, G.; Vernieres, M.-C.; Badre, S.; Méallet-Renault, R. Synthesis and Properties of New Tetrazines Substituted by Heteroatoms: Towards the World's Smallest Organic Fluorophores. Chem. Eur. J. 2005, $11,5667$. (c) Gong, Y.-H.; Miomandre, F.; Meallet-Renault, R.; Badre', S.; Galmiche, L.; Tang, J.; Audebert, P.; Clavier, G. Synthesis and Physical Chemistry of s-Tetrazines: Which Ones are Fluorescent and Why? Eur. J. Org. Chem. 2009, 6121. (d) Jullien-Macchi, E.; Allain, C.; Alain-Rizzo, V.; Dumas-Verdes, C.; Galmiche, L.; Audibert, J.F.;Berhe Desta, M.; Pansu, R. B.; Audebert, P. New Highly Electrodeficient Cationic Fluorescent Tetrazines: a Step Toward the Strongest Purely Organic Photooxidants. New J. Chem. 2014, 38, 3401. (e) Jullien-Macchi, E.; Alain-Rizzo, V.; Allain, C.; Dumas-Verdes, C.; Audebert, P. s-Tetrazines functionalized with phenols: synthesis 
and physico-chemical properties. $R S C A d v$. 2014, 4, 34127. (f) Qing, Z.; Audebert, P.; Clavier, G.; Miomandre, F.; Tang, J.; Vu, T. T.; Meallet-Renault, R. Tetrazines with Hindered or Electron Withdrawing Substituents: Synthesis, Electrochemical and Fluorescence Properties. J. Electroanal. Chem. 2009, 632, 39.

(7) (a) Gückel, F.; Maki, A. H.; Neugebauer, F. A.; Schweitzer, D.; Vogler, H. Spectroscopic Investigations of the Lowest Triplet-State of s-Tetrazines. Chem. Phys. 1992, 164, 217. (b) Myers, T. W.; Snyder, C. J.; Chavez, D. E.; Scharff, R. J.; Veauthier, J. M. Synthesis and Electrochemical Behavior of Electron-Rich s-Tetrazine and Triazolotetrazine Nitrate Esters. Chem. Eur. J. 2016, 22, 10590. (c) Chavez, D. E.; Parrish, D. A.; Mitchell, L. Energetic Trinitro- and Fluorodinitroethyl Ethers of 1,2,4,5-Tetrazines. Angew. Chem., Int. Ed. 2016, 55, 8666.

(8) (a) Samanta, S.; Das, S.; Biswas, P. Photocatalysis by 3,6- Disubstituted-s-Tetrazine: Visible-Light Driven Metal-Free Green Synthesis of 2-Substituted Benzimidazole and Benzothiazole. J. Org. Chem. 2013, $78,11184$. (b) Samanta, S.; Biswas, P. Metal Free Visible Light Driven Oxidation of Alcohols to Carbonyl Derivatives Using 3,6-Di(pyridin-2-yl)-1,2,4,5-tetrazine (pytz) as catalyst. RSC Adv. 2015, 5, 84328. (c) Samanta, S.; Ray, S.; Ghosh, A. B.; Biswas, P. 3,6- Di(pyridin-2-yl)-1,2,4,5-tetrazine (pytz) Mediated Metal-Free Mild Oxidation of Thiols to Disulfides in Aqueous Medium. RSC Adv. 2016, 6, 39356.

(9) (a) Chowdhury, M.; Goodman, L. Nature of s-Tetrazine Emission Spectra. J. Chem. Phys. 1963, 38, 2979. (b) Ågren, H.; Vahtras, O.; Knuts, S.; Jørgensen, P. Radiative Lifetimes of Triplet Spin Sublevels of the Azabenzenes. Chem. Phys. 1994, 181, 291.

(10) (a) Kuriyama, Y.; Arai, T.; Sakuragi, H.; Tokumaru, K. Effects of Sensitizer Spin Multiplicity on ElectronTransfer Initiated Isomerization of cis-Stilbene. Chem. Lett. 1988, 17, 1193. (b) Akaba, R.; Ohshima, K.; Kawai, Y.; Obuchi, Y.; Negishi, A.; Sakuragi, H.; Tokumaru, K. Triplet-Mediated Electron Transfer Oxygenation of Stilbene Derivatives with 2,4,6-Triphenylpyrylium Tetrafluoroborate. Tetrahedron Lett. 1991, 32, 109.

(11) Wever, W. J.; Cinelli, M. A.; Bowers, A. A. Visible Light Mediated activation and O-Glycosylation of Thioglycosides. Org. Lett. 2013, 15, 30.

(12) Chlorocyclohexane was totally recovered at the end of the reaction.

(13) For a selected review on superoxide anion radical acting as a base, see: Hayyan, M.; Hashim, M. A.; AlNashef, I. M. Superoxide Ion: Generation and Chemical Implications. Chem. Rev. 2016, 116, 3029.

(14) Samoilova, R. I.; Crofts, A. R.; Dikanov, S. A. Reaction of Superoxide Radical with Quinone Molecules. J. Phys. Chem. A 2011, 115, 11589.

(15) Hsu, C.-W.; Sunden, H.' $\alpha$-Aminoalkyl Radical Addition to Maleimides via Electron Donor-Acceptor Complexes. Org. Lett., 2018, 20, 2051.

(16) George, N.; Bekkaye, M.; Masson, G.; Zhu, J. A Practical, OnePot Multicomponent Synthesis of $\alpha$ Amidosulfides and Their Application as Latent N-Acylimines in the Friedel-Crafts Reaction., Eur. J. Org. Chem. 2011, 3695. 